\title{
Marine diatoms from Buenos Aires coastal waters (Argentina). V. Species of the genus Chaetoceros
}

\author{
Diatomeas marinas de aguas costeras de Buenos Aires (Argentina). \\ V. Especies del género Chaetoceros \\ Inés Sunesen ${ }^{1}$, David U. Hernández-Becerril ${ }^{2}$ and Eugenia A. Sar ${ }^{1,3}$ \\ ${ }^{1}$ Departamento Científico Ficología, Facultad de Ciencias Naturales y Museo, Universidad Nacional de La Plata, \\ Paseo del Bosque s/n, 1900, La Plata, Argentina \\ ${ }^{2}$ Instituto de Ciencias del Mar y Limnología, Universidad Nacional Autónoma de México, \\ Apdo. postal 70-305, México, D. F. 04510, México \\ ${ }^{3}$ Consejo Nacional de Investigaciones Científicas y Técnicas, Av. Rivadavia 1917, Ciudad Autónoma de Buenos Aires, Argentina \\ isunesen@fcnym.unlp.edu.ar
}

\begin{abstract}
Resumen.- El género Chaetoceros es un componente importante del plancton marino, de amplia distribución mundial en términos de diversidad y biomasa. El presente trabajo está abocado a la morfología, taxonomía y distribución de las especies pertenecientes al género Chaetoceros encontradas en aguas costeras marinas de la Provincia de Buenos Aires, Argentina. Las muestras fitoplanctónicas fueron recolectadas desde noviembre de 1994 hasta septiembre de 2000 en siete estaciones ubicadas a lo largo de la costa bonaerense entre los paralelos $36^{\circ} 20^{\prime}$ y $37^{\circ} 20^{\prime} \mathrm{S}$. El material fue estudiado con microscopía óptica y electrónica de barrido. Veinte taxa fueron encontrados, identificados, descriptos, ilustrados y comparados con los taxa más allegados. Tres de esos taxa pertenecen al subgénero Chaetoceros (= Phaeoceros) y los restantes diecisiete pertenecen al subgénero Hyalochaete. Chaetoceros filiferus y C. compressus var. hirtisetus son reportados por primera vez para el Océano Atlántico sudoccidental. C. danicus, C. debilis, C. lorenzianus y $C$. socialis, mencionadas como especies nocivas en otras áreas geográficas, no fueron asociados a eventos nocivos en el área de estudio durante este período.
\end{abstract}

Palabras clave: Bacillariophyceae, morfología, diatomeas nocivas

\begin{abstract}
The genus Chaetoceros is an important component of the marine plankton all over the world in terms of diversity and biomass. The present work is devoted to the morphology, taxonomy, and distribution of the diatom species belonging to the genus Chaetoceros found in the marine coastal waters of Buenos Aires Province, Argentina. Phytoplanktonic samples were collected from November 1994 to September 2000 at seven sampling stations along the coast between parallels $36^{\circ} 20^{\prime}$ and $37^{\circ} 20^{\prime}$ 'S. Material was studied by light and scanning electron microscopy. Twenty taxa were found, identified, described, illustrated and compared with allied taxa. Three of these taxa belong to the subgenus Chaetoceros (= Phaeoceros) and the other seventeen taxa to the subgenus Hyalochaete. Chaetoceros filiferus and C. compressus var. hirtisetus are reported for the first time from south western Atlantic Ocean. C. danicus, C. debilis, C. lorenzianus and C. socialis, mentioned as harmful in other geographical areas, were not associated with harmful events in the study area.
\end{abstract}

Key words: Bacillariophyceae, morphology, harmful diatoms

\section{Introduction}

Chaetoceros Ehrenberg is a planktonic diatom genus, common in marine environments all over the world, either in neritic or oceanic waters, with only a few species from continental or estuarine environments. This genus together with Coscinodiscus and Thalassiosira are considered the marine planktonic genera with highest species diversity and widest distribution (Rines \& Hargraves 1988, Jensen \& Moestrup 1998).

Chaetoceros comprises diatoms with bipolar valves and setae of different structure to the valves. The species of Chaetoceros very often form chains and only a few are solitary. There are various ways of connections in the chains such as fusion of setae, fusion of edge valves and setae, holding of setae, presence of prehensors, siliceous walls, and fusion of linking spines. Traditionally the identification at species level has been based on morphological features observed by light microscopy: morphology of the colonies, shape and dimensions of cells, thickness and direction of setae, number and shape of chloroplasts, presence and morphology of resting spores. However, some other features, which can mostly be seen by electron microscopy, as fine structure of valves and setae, and location and number of rimoportulae are now considered to be relevant in morphological studies. 
Due to the high morphological diversity of the genus, it has a complicated classification into three subgenera and more than twenty sections (Ostenfeld 1903, Gran 1908, Hernández-Becerril 1993a, 1996, HernándezBecerril \& Flores Granados 1998, Rines \& Theriot 2003). This classification system has been questioned recently by Rines \& Hargraves (1988) and Rines \& Theriot (2003), as there are many inconsistencies.

Blooms produced by several Chaetoceros species are considered harmful. Some species of the subgenus Chaetoceros (= Phaeoceros) with large and robust setae, as C. convolutus Castracane, C. concavicornis Manguin and C. danicus Cleve, may mechanically harm fish gills (Clément \& Lembeye 1993, Horner et al. 1997, Fryxell \& Hasle 2004, Smayda 2006). Some other species belonging to the subgenus Hyalochaete Lauder, may occlude fish gills by forming mucilaginous colonies as C. socialis, or may cause hungerless, lethargy and eventually death of fishes, as $C$. wighamii Brightwell, $C$. debilis Cleve and C. socialis (Smayda 2006).

Fifty-eight taxa of Chaetoceros have been previously recorded from Argentinian marine waters (Vouilloud 2003) most of them without ultrastructural analysis. Only a few species include studies by electron microscopy: $C$. didymus Ehrenberg (Ferrario et al. 1986, Sar 1996) and C. tenuissimus Meunier (Sar et al. 2002). The study of Argentinian material might contribute to show ultrastructural features of those taxa not previously illustrated and to add information for biogeographical studies. The purpose of this paper is to provide an account of the genus Chaetoceros in the study area with remarks on morphology, taxonomy, distribution and comparison with allied species. This paper also identifies noxious bloom producers in other areas and the relationships between detected harmful species and registered harmful events in the study area.

\section{Material and methods}

Material was collected along the coast of Buenos Aires Province (Argentina) between parallels $36^{\circ} 20^{\prime}$ and $37^{\circ} 20^{\prime}$ S, at seven sampling stations: San Clemente del Tuyú, Santa Teresita, La Lucila del Mar, Mar de Ajó, Nueva Atlantis, Pinamar and Villa Gesell (Fig. 1). Samples were taken seasonally during the period November 1994 to October 1996, bimonthly from October 1996 to January 1999 and monthly from October 1999 to September 2000. Two hundred and eleven qualitative samples were taken by $30 \mu \mathrm{m}$ net hauled in the upper $5 \mathrm{~m}$ of the water column and fixed with $4 \%$ formaldehyde.

Material was treated to eliminate organic matter following Hasle \& Fryxell (1970) and Prygiel \& Coste

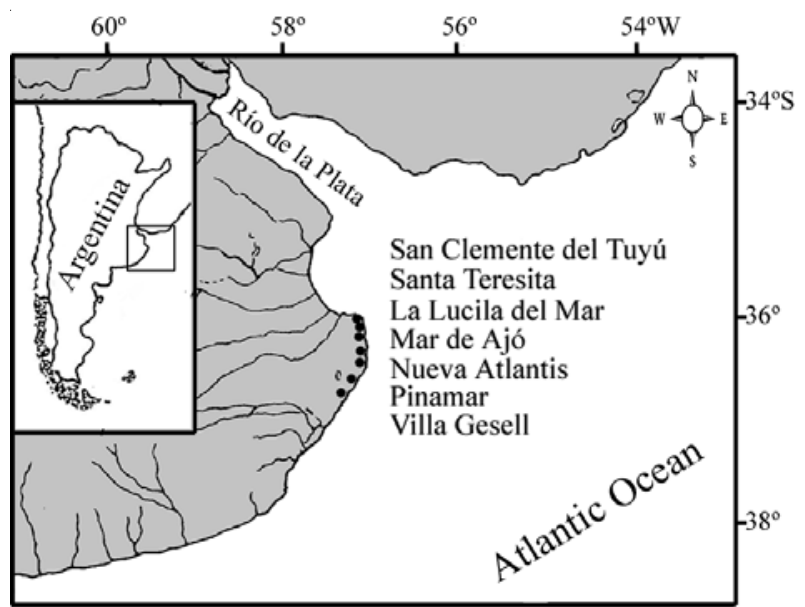

Figure 1

Map of Buenos Aires Province showing the sampling stations and location of the area in Argentina

Mapa de la Provincia de Buenos Aires mostrando las estaciones de muestreo y la localización del área en Argentina

(2000). The cleaned material was mounted for the light and scanning electron microscope analyses according to Ferrario et al. (1995). Raw and treated samples, and permanent slides correlatively labeled were incorporated to the Colección de Diatomeas Argentinas, deposited at the Departamento Científico Ficología, Facultad de Ciencias Naturales y Museo, Universidad Nacional de La Plata under the numbers LPC 4250 to 4449 and 4485 to 4495 (Table 1).

Observations and photomicrographs were made with light microscopes (LM) Wild M20 and Nikon Microphot FX using phase contrast and with scanning electron microscopes (SEM) Jeol JSMT 100 and Jeol JSM 6360 LV.

The catalogues considered to identify previous reports of each taxon from Argentina were Ferrario \& Galván (1989) and Vouilloud (2003). Terminology followed general proposals by Anonymous (1975), Ross et al. (1979), Round et al. (1990) and Nikolaev (1993), and specifically for Chaetoceros by Brunel (1966, 1972), Rines \& Hargraves (1988), Hernández-Becerril (1996) and Jensen \& Moestrup (1998).

\section{Results and discussion}

\section{Subgenus Chaetoceros (=Phaeoceros)}

Chaetoceros danicus Cleve (Fig. 2A-G)

Rines \& Hargraves 1988, p. 49, figs. 95-99; HernándezBecerril 1996, p. 16, pl. 13, figs. 1-7, pl. 14, figs. 1-8; 
Table 1

List of the phytoplankton samples collected in the coastal waters of the Buenos Aires Province and stored at the Colección de Diatomeas Argentinas. SC = San Clemente del Tuyú, ST = Santa Teresita, $\mathbf{L L}=$ La Lucila del Mar, MA = Mar de Ajó, NA = Nueva Atlantis, PI = Pinamar and VG = Villa Gesell

Tabla 1. Lista de muestras de fitoplancton recolectadas en aguas costeras de la Provincia de Buenos Aires y depositadas en la Colección de Diatomeas Argentinas. $\mathrm{SC}=$ San Clemente del Tuyú, ST = Santa Teresita, LL = La Lucila del Mar, MA $=$ Mar de Ajó, $\mathrm{NA}=$ Nueva Atlantis, $\mathrm{PI}=$ Pinamar y VG $=$ Villa Gesell

\begin{tabular}{lccccccc}
\hline Date/Fecha & SC & ST & LL & MA & NA & PI & VG \\
\hline Nov. 1994 & & 4250 & & 4251 & 4252 & & 4253 \\
Jan. 1995 & & 4254 & & 4255 & 4256 & & 4257 \\
Mar. 1995 & & 4258 & & 4259 & 4260 & 4263 & 4264 \\
Nov. 1995 & & 4266 & 4267 & 4268 & 4269 & 4270 & 4271 \\
Jan. 1996 & & 4272 & 4273 & 4274 & 4275 & 4276 & 4277 \\
April 1996 & 4279 & 4280 & 4281 & 4282 & 4283 & 4284 & 4285 \\
June 1996 & 4286 & 4287 & 4288 & 4289 & & 4290 & 4291 \\
Sept. 1996 & 4292 & 4293 & & 4294 & & 4295 & 4296 \\
Nov. 1996 & 4297 & 4298 & 4299 & 4300 & & & 4301 \\
Jan. 1997 & 4302 & 4303 & 4304 & 4305 & $4306 / 7$ & 4308 & 4309 \\
Mar. 1997 & 4310 & 4311 & 4312 & 4313 & & 4314 & 4315 \\
May 1997 & 4316 & 4317 & 4318 & 4319 & & 4320 & 4321 \\
July 1997 & 4322 & 4323 & 4324 & 4325 & & 4326 & \\
Sept. 1997 & 4327 & 4328 & 4329 & 4330 & & 4331 & \\
Nov. 1997 & 4332 & 4333 & 4334 & 4335 & & 4336 & 4337 \\
Jan. 1998 & 4338 & 4339 & 4340 & 4341 & & 4342 & 4343 \\
Mar. 1998 & 4344 & 4345 & 4346 & 4347 & & 4348 & 4349 \\
May 1998 & 4250 & 4351 & 4352 & 4353 & & 4354 & 4355 \\
July 1998 & 4356 & 4357 & 4358 & 4359 & & 4360 & 4361 \\
Sept. 1998 & 4362 & 4363 & 4364 & 4365 & & 4366 & 4367 \\
Dec. 1998 & 4368 & 4369 & 4370 & 4371 & & 4372 & 4373 \\
Jan. 1999 & 4374 & 4375 & 4376 & 4377 & & 4378 & 4379 \\
Oct. 1999 & 4384 & 4385 & 4386 & 4387 & & 4388 & 4389 \\
Nov. 1999 & 4390 & $4391 / 2$ & 4393 & 4394 & & 4395 & 4396 \\
Dec. 1999 & 4398 & $4399 / 4400$ & 4401 & 4402 & & 4403 & 4404 \\
Jan. 2000 & 4405 & 4406 & 4407 & & & 4408 & 4409 \\
Feb. 2000 & 4410 & $4411 / 2$ & 4413 & 4414 & & 4415 & 4416 \\
Mar. 2000 & 4417 & 4418 & 4419 & 4420 & & 4421 & 4422 \\
April 2000 & 4423 & $4424 / 5$ & 4426 & 4427 & & 4428 & 4429 \\
May 2000 & 4430 & $4431 / 2$ & 4433 & 4434 & & 4435 & 4436 \\
June 2000 & 4437 & 4438 & 4439 & 4440 & & 4441 & 4442 \\
Suly 2000 & 4443 & 4444 & 4445 & 4446 & & 4447 & 4448 \\
Sept & 4449 & 4485 & 4486 & 4487 & & 4488 & 4489 \\
& & & 4492 & 4493 & & 4494 & 4495 \\
\hline
\end{tabular}

Jensen \& Moestrup 1998, p. 15, figs. 10-15.

Cells either solitary (Fig. 2A) or in straight and short chains (usually up to three cells) (Fig. 2C). Apertures narrow. Frustules rectangular in girdle view (Fig. 2A). Valves elliptical to nearly circular in outline (Fig. 2B, D, E). Valve face flat to convex, perforated by poroids (Fig. 2E). Mantle high with a constriction near the margin (Fig. 2C). Rimoportula on each valve, centrally located, with an externally flat, short tube and an internally elliptical hole (Fig. 2B, D, E). Setae long and thick, arising from the corners of the valves, circular in cross section at the base and quadrangular to polygonal distally, with transverse striae and longitudinal costae bearing spines (Fig. 2D, F, G). Terminal setae diverging perpendicular to the pervalvar axis.

Measurements: apical axis, 16-24 $\mu \mathrm{m}$.

Distribution and abundance: Chaetoceros danicus was previously reported from the area by Lange (1985). During the present study this species occurred in spring, fall and winter at all stations; rare.

Remarks: In the western coast of USA Chaetoceros danicus has been involved in mass mortality of fishes by anoxia, due to the gill clogging caused by the mucus production generated in response to the damage of spines on the gills (Horner et al. 1997).

\section{Chaetoceros peruvianus Brightwell (Fig. 3A-D)}

Koch \& Rivera 1984, p. 69, figs. 36-47; Rines \& Hargraves 1988, p. 53, figs. 108-112; Hernández-Becerril 1996 , p. 22 , pl. 16, figs. 1-6, pl. 17, figs. 1-9.

Cells solitary, heterovalvar (Fig. 3A, B). Frustule cylindrical in girdle view. Anterior valve convex (Fig. 3C) and posterior valve flat or concave (Fig. 3A, B). Mantle high with a constriction near the margin (Fig. 3C). Rimoportula on each valve, eccentrically located in the annulus with external, flattened tube (Fig. 3C). Setae of anterior valve fused together after a short base in the valve centre (Fig. 3C), setae of posterior valve arising from the corners (Fig. 3 A, B). All setae directed towards the same end of the cell, thick (3-4 $\mu \mathrm{m})$, four-sided in cross section, covered by poroids ordered in bi to triseriate transverse striae between internal transverse costae and longitudinal rows of spines (Fig. 3D). Girdle narrow.

Measurements: apical axis, 10-44 $\mu \mathrm{m}$.

Distribution and abundance: Chaetoceros peruvianus has been frecuently reported from the Argentinian Sea (Ferrario \& Galván 1989). During the present study this species was found throughout the year at all stations, rare.

Chaetoceros rostratus Lauder (Fig. 3E-H)

Giuffrè \& Ragusa 1988, p. 503, figs. 1-23; Rines \& Hargraves 1988, p. 55, figs. 105-117; Hernández-Becerril 1996, p. 16, pl. 11, figs. 1-6, pl.12, figs. 1-7. 

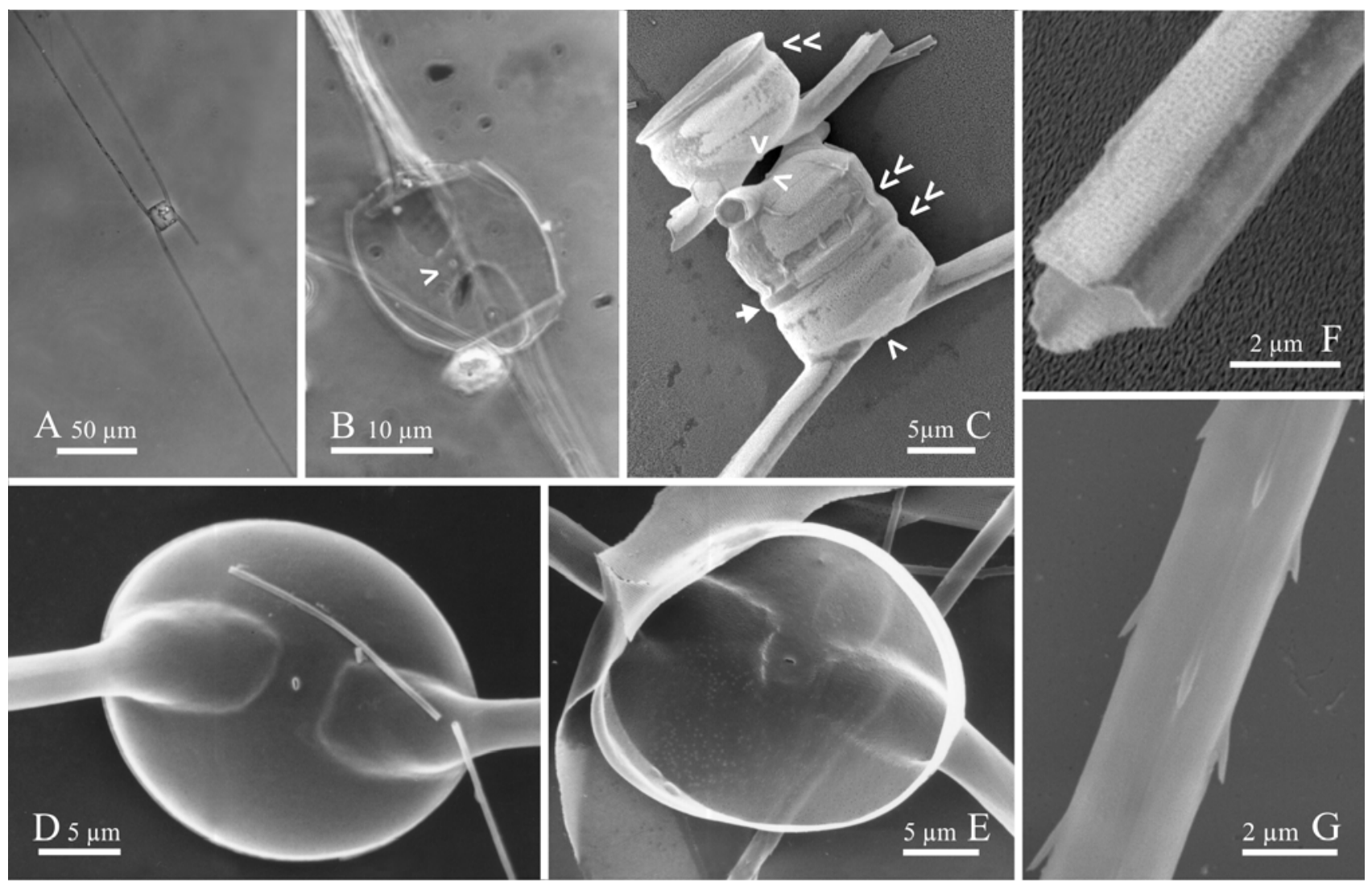

Figure 2

Chaetoceros danicus. (A and B. LM; C-G. SEM) A. Cell. B. Valve showing the basal part of the setae and the central process. C. Whole cell with a sibling valve. Note the presence of a central process in each valve (arrowheads), the constriction on the basal part of the mantle (double arrowheads) and the girdle (arrow). D. Valve in external view.

E. Valve in internal view. Note the scattered poroids on the valve face and the central rimoportula without internal labiate structure. $F$ and G. Details of the setae showing the quadrangular section, the pattern of striation and the distribution of the spines, in longitudinal, secondarily spiraled rows along the setae

Chaetoceros danicus. (A y B. Microscopio óptico [MO]; C-G. Microscopio electrónico de barrido [MEB]) A. Célula. B. Valva mostrando la parte basal de las setas y el rimoportula central. C. Célula entera con una valva adyacente. Note la presencia de un rimoportula central en cada valva (flechas), la constricción en la parte basal del manto (flechas dobles) y la cintura (flecha rellena).

D. Valva en vista externa. E. Valva en vista interna. Note los poroides esparcidos en la superficie valvar y el rimoportula central

sin estructura labiada interna. F y G. Detalles de las setas mostrando la sección transversal cuadrangular, el patrón de estriación y la distribución de espinas en hileras longitudinales secundariamente espiraladas a lo largo de las setas

Cells solitary or united in short, straight chains by a central valve connecting process (Fig. 3E, F). Frustules subrectangular in girdle view (Fig. 3E). Valves elliptical to circular with costae running from the centre and poroids randomly spread (Fig. 3G). Valve surface conical. Mantle high, perforated by poroids denser than in the valve surface (Fig. 3F). Connecting processes hollow (Fig. 3G), variable in length and width. Rimoportula on each valve, eccentrically located, with a short external tube (Fig. 3F).
All setae thick, straight, four or five-sided in crosssection, with large spines on the edges (Fig. 3 H). Sibling setae not fused together.

Measurements: apical axis, 14.5-17 $\mu \mathrm{m}$.

Distribution and abundance: Chaetoceros rostratus has been previously reported by Frenguelli (1928) and Lange (1985) off Mar del Plata coast. During the present study 

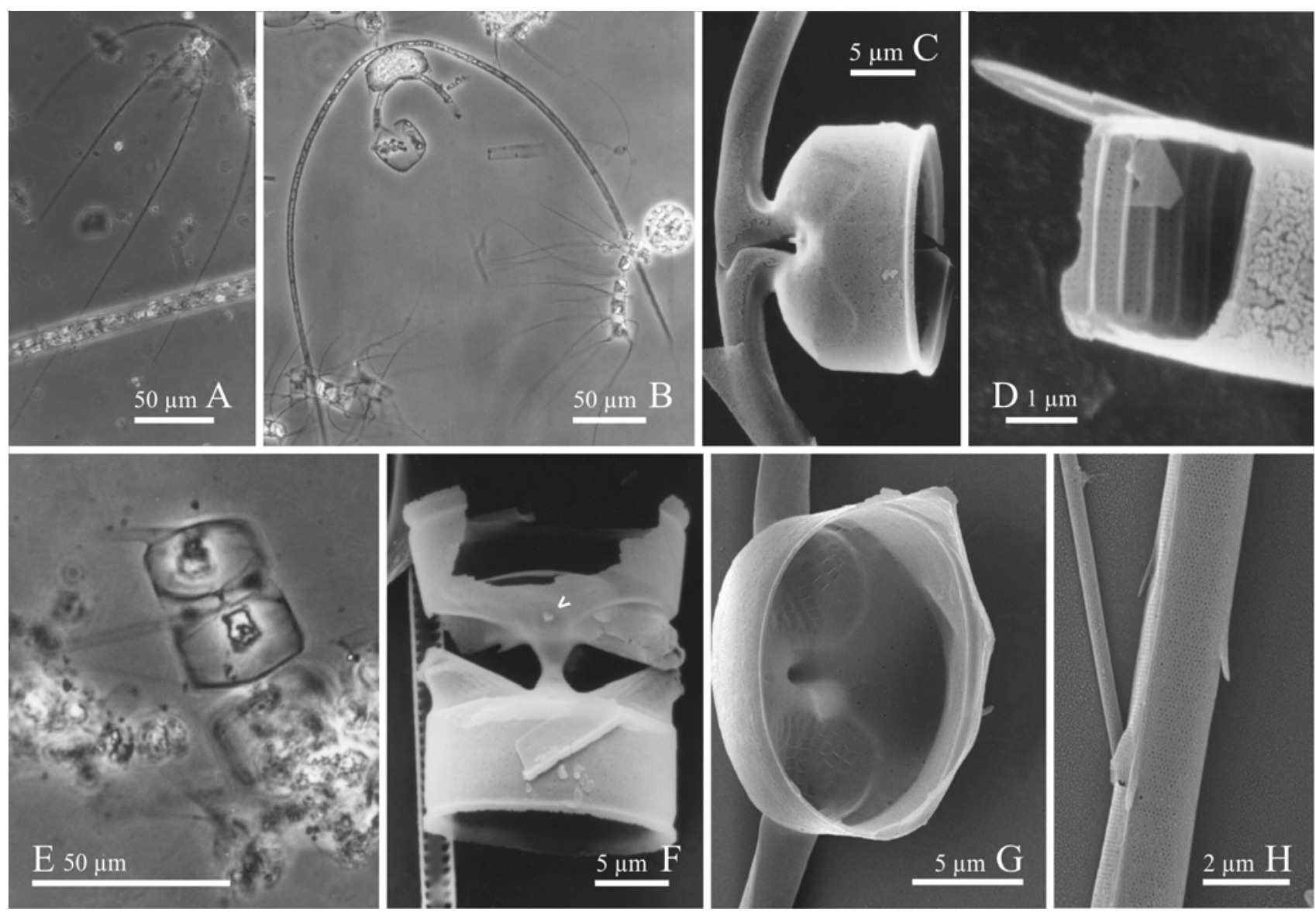

Figure 3

Chaetoceros spp. (A, B and E. LM; C, D, F-H. SEM) A-D. Chaetoceros peruvianus. A and B. Cells, note the differences in the lenght-wide ratio of the cells. C. Detail of a convex valve in external view showing the flattened tube of the rimoportula and the basal parts of the setae. D. Detail of a seta, note the striation pattern, the transverse costae and the position of the spines. E-H. Chaetoceros rostratus. E. Part of a chain. F. Two sibling valves showing the intervalvar connecting process and the aperture of the rimorportula on the upper valve (arrow). G. Valve in internal view, note the structure of the basal part of the setae and the scattered poroid on the valve surface. $H$. Detail of the setae with spines on the edges

Chaetoceros spp. (A, B y E. MO; C, D, F-H. MEB) A-D. Chaetoceros peruvianus. A y B. Células, note las diferencias en la relación largo/ancho de las células. C. Detalle de una valva convexa en vista externa mostrando el tubo aplanado del rimoportula y la parte basal de las setas. D. Detalle de una seta, note el patrón de estriación, las costillas transversales y la posición de las espinas. E-H. Chaetoceros rostratus. E. Parte de una cadena. F. Dos valvas adyacentes mostrando el proceso de conexión intervalvar y la abertura del rimoportula en la valva superior (flecha). G. Valva en vista interna, note la estructura de la parte basal de las setas y los poroides esparcidos en la superficie valvar. H. Detalle de las setas con espinas en las aristas

this species was found in Pinamar station in May 1998, rare.

\section{Subgenus Hyalochaete}

\section{Chaetoceros affinis Lauder (Fig. 4A-C)}

Evensen \& Hasle 1975, p. 161, figs. 46-54; Rines \& Hargraves 1988, p. 59, figs. 113-114; Hernández-Becerril 1996 , p. 35, pl. 27, figs. 1-7, pl. 28, figs. 1-7; Jensen \&
Moestrup 1998, p. 20, figs. 30-43.

Cells in straight chains, usually long (Fig. 4A). Apertures elliptical to lanceolate. One large chloroplast per cell. Frustule rectangular in girdle view. Valve elliptical in outline (Fig. 4B). Valve surface slightly concave. Mantle high. Rimoportula centrally located on terminal valves only. Intercalary setae, circular in cross-section, with rows of small spines and poroids, diverging at an angle of 10- 

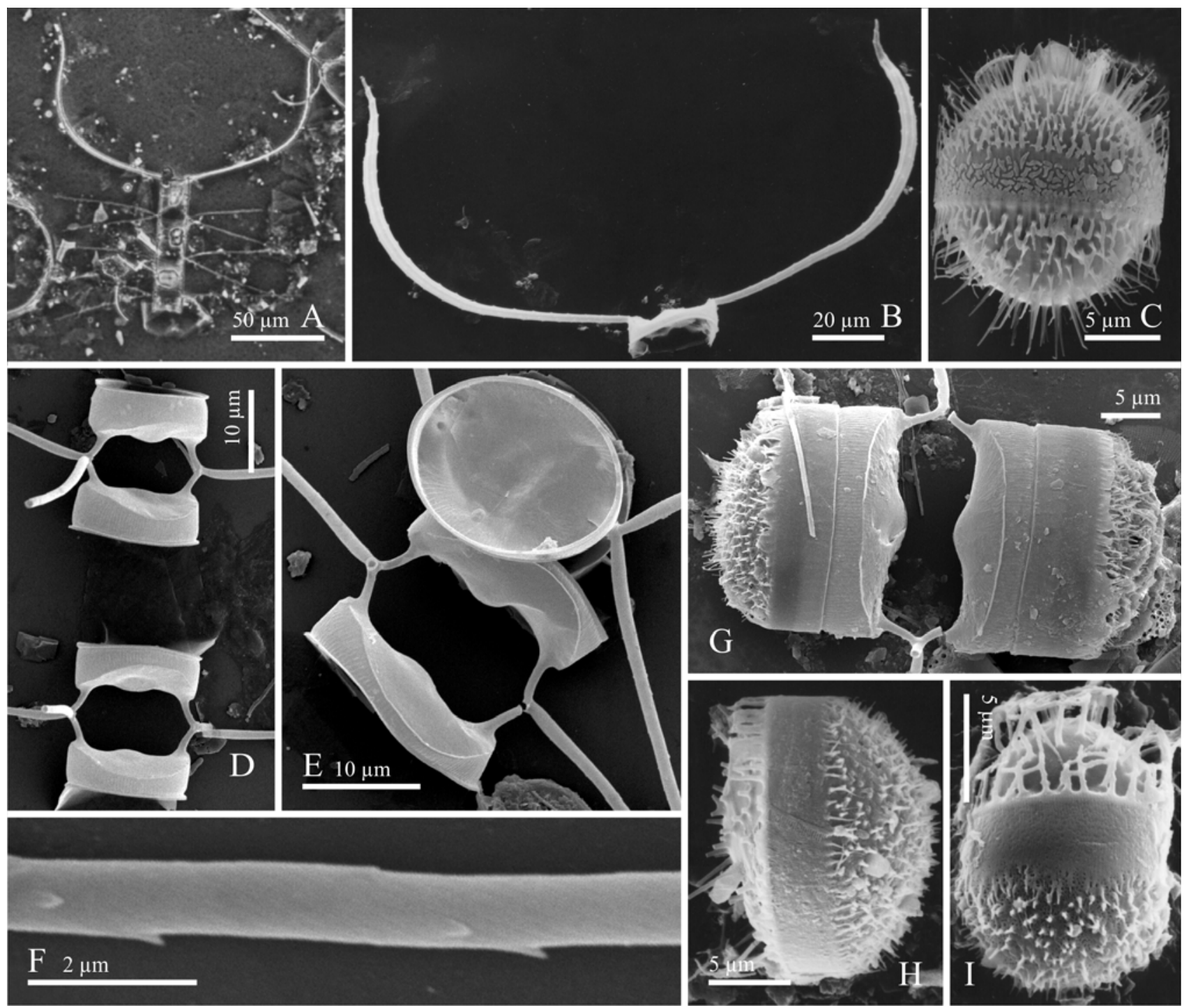

Figure 4

Chaetoceros spp. (A. LM; B-I. SEM) A-C. Chaetoceros affinis. A. Part of a chain, showing the terminal valve with strong, thick setae and the intercalary valves with thin setae. $B$. Terminal valve. $C$. Resting spore with both valves covered by delicate spines. D-I. Chaetoceros brevis. D. Part of a broken chain. E. Pairs of sibling valves in valve and girdle views, note the broadly elliptical to subcircular valve outline, the structure of the valve wall and the hyaline ridge between valve face and mantle. F. Detail of seta with spirals of minute spines and poroids. G. Part of a chain with two resting spores. H-I. Resting spores showing the primary valve covered by a superficial silicious framework with small spines and the secondary valve smooth with bigger spines

Chaetoceros spp. (A. MO; B-I. MEB) A-C. Chaetoceros affinis. A. Parte de una cadena mostrando la valva terminal con setas gruesas, robustas y valvas intercalares con setas finas. B. Valva terminal. C. Estatospora con ambas valvas cubiertas por espinas

delicadas. D-I. Chaetoceros brevis. D. Parte de una cadena degradada. E. Pares de valvas vecinas en vistas valvar y cingular, note el contorno valvar anchamente elíptico a subcircular, la estructura de la pared valvar y la costilla hialina entre la superficie valvar y el manto. F. Detalle de una seta con pequeñas espinas y poroides ordenados en hileras espiraladas. G. Parte de una cadena con dos estatosporas. H-I. Estatosporas mostrando la valva primaria cubierta por un gran número de espínulas pequeñas sobre un entramado superficial y la valva secundaria con espinas mayores sobre una superficie lisa 
$30^{\circ}$ from the chain axis (Fig. A). Terminal setae thicker than intercalary setae, curving smoothly (in U or V shape) to the chain axis, polygonal in cross-section, with large spines in spirals (Fig. 4B). Resting spores spiny with convex valves (Fig. 4C).

Measurements: apical axis, 16-27 $\mu \mathrm{m}$.

Distribution and abundance: Chaetoceros affinis has been frequently reported from the Argentinian Sea (Ferrario \& Galván 1989, Vouilloud 2003). During the present study this species occured in spring, summer and fall at all stations, rare.

\section{Chaetoceros brevis Schütt (Fig. 4D-I)}

Hernández-Becerril 1996, p. 38, pl. 32, figs. 1-6, pl. 33, figs. 1-5; Jensen \& Moestrup 1998, p. 24, figs. 49-62.

Cells in straight chains. Aperture wide with a slight constriction in the middle (Fig. 4D, E). Frustules rectangular in girdle view, with rounded apices. Valve elliptical to subcircular in outline, with costae (Fig. E). Valve face inflated (Fig. D, E). Mantle vertical, variable in height (Fig. D, E). All setae thin and delicate, with spirals of minute spines and poroids (Fig. 4F). Intercalary setae arising inside from the margins of the valves (not exactly the corners) with long basal part (Fig. 4D, E). Resting spores originated in pairs, spiny, with unequally convex valves (Fig. G-I). Primary valve covered by a superficial siliceous framework with short spines. Secondary valve smooth with long spines.

Measurements: apical axis, 9-26 $\mu \mathrm{m}$.

Distribution and abundance: Chaetoceros brevis has been previously reported by Müller-Melchers (1955) from Necochea and by Balech (1964) from Mar del Plata. During the present study the species appeared in summer at Pinamar and Villa Gesell stations, rare.

Chaetoceros compressus Lauder var. hirtisetus Rines \& Hargraves (Fig. 5A-F)

Rines \& Hargraves 1990, p. 114, figs. 1-29; Shevchenko et al. 2006, p. 242, figs. 35-39.

Synonym Chaetoceros sp. C, Rines \& Hargraves 1998, p. 104, figs. 212-217.

Cells in straight chains usually twisted about the pervalvar axis. Cells rectangular to cuadrangular in girdle view. Rimoportula centrally located on terminal valves only. Two types of intercalary setae, common and special. The common setae thin and delicate, bearing small spines and with capilli at the proximal part, diverging almost pependicular to the chain axis. The special setae thick, coarse, curved, with large spines, spirally twisted; directed to the chain end. Terminal setae thin and delicate, directed almost parallel to the chain axis. Sibling setae fusing after a short basal part (Fig. 5A). Resting spores circular to elliptical in outline (Fig. 5C) with convex valves (Fig. $5 \mathrm{~A}, \mathrm{~B}, \mathrm{D})$. Primary valve with valve surface and mantle covered by delicate granules and a ring of strong spines on the valve margin close to mantle (Fig. 5D, F). Secondary valve with one or two pattern centres (Fig. $5 \mathrm{E})$, bearing bigger granules arranged in striae and two knobs near the poles of apical axis (Fig. 5C).

Measurements: apical axis, 8.5-24 $\mu \mathrm{m}$.

Distribution and abundance: Chaetoceros compressus var. hirtisetus was found in summer, fall and spring at San Clemente del Tuyú, La Lucila del Mar and Pinamar stations, rare.

Remarks: Chaetoceros compressus var. hirtisetus is a new record for the South Western area of the Atlantic Ocean.

Chaetoceros contortus Schütt (Fig. 5G-M)

Rines \& Hargraves 1988, p. 64, figs. 131-134, 218 (as C. compressus); Jensen \& Moestrup 1998, p. 33, figs. 95103; Rines 1999, p. 541, figs. 7-43.

Cells in long chains straight, twisted about the chain axis (Fig. 5G). Apertures relatively wide and centrally slightly constricted (Fig. 5G). Cells with several small chloroplasts. Frustules rectangular with rounded corners in girdle view (Fig. 5G). Valves broadly elliptical to circular (Fig. 5H, J). Valve surface almost flat. Intercalary setae of two types, common and special. The common setae thin, delicate with small spines, almost perpendicular to the chain axis (Fig. 5G). The special setae thick, coarse, with large spines arrange in spirals, curved, tapering distally, directed to the chain axis (Fig. 5H-K). Setae arising from inside the margins of the valves (Fig. 5G, J). Resting spores with convex valves. Primary valve with various small knobs (Fig. 5M), secondary valve smooth, surrounded by a irregularly perforated collar (Fig. 5L).

Measurements: apical axis, 10-17 $\mu \mathrm{m}$.

Distribution and abundance: Chaetoceros contortus has been previously reported by Marques da Cunha \& Da Fonseca (1917) and Balech (1976) from the Argentinian Sea. During the present study this species appeared throughout the year at all stations, rare.

\section{Chaetoceros curvisetus Cleve (Fig. 6A-F)}

Hargraves 1979, p. 105, figs. 35-41; Hernández-Becerril 1996, p. 53, pl. 42, figs. 1-6, pl. 43, figs. 1-5; Shevchenko et al. 2006, p. 245, figs. 43-46. 

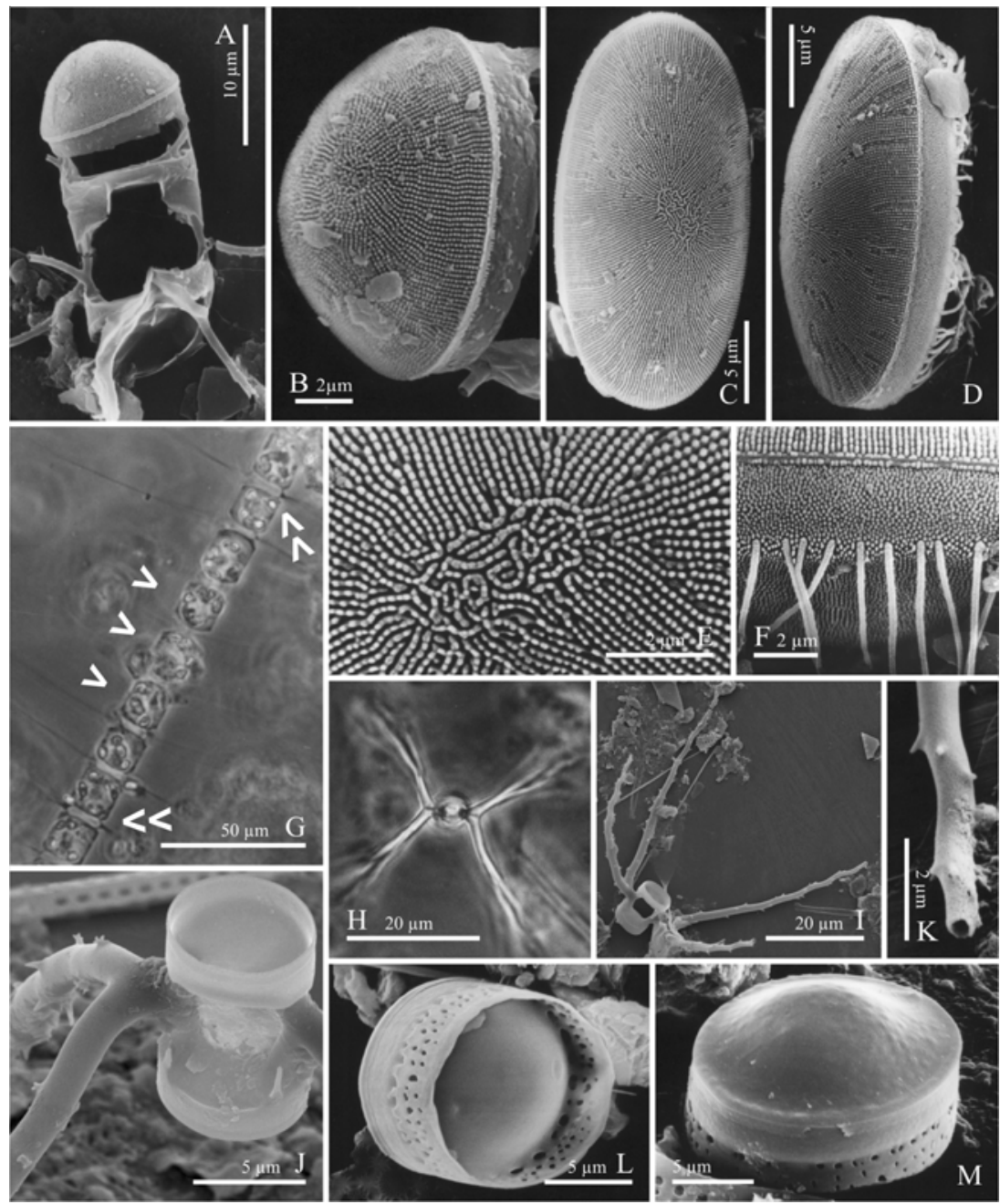

Figure 5

Chaetoceros spp. (A-F, I-M. SEM; G and H. LM) A-F. Chaetoceros compressus var. hirtisetus. A. Part of a broken chain with a resting spore. B. Detail of the resting spore of fig. 5A. C and D. Resting spore in valve and girdle view respectively. E. Detail of the annulus of the resting spore of fig. 5C. Note the ornamentation of the secondary valve of the resting spore. F. Detail of fig. 5D showing the delicate structure of the wall on the primary valve of the resting spore. Note the palisade of spines from the mantle of this valve. G-M. Chaetoceros contortus. G. Part of a chain. Note the cells twisted about the pervalvar axis (arrowhead), all cells with the same outline and setae with oblique basal part, fusing at the edge of the colony (double arrowheads). H-J. Intercalary valves with thick, heavily silicified setae.

Note in fig. $5 \mathrm{H}$ the complex spinulae in the proximal part of the setae. K. Detail of the distal part of heavily silicified setae. Note circular cross section and the presence of simple spines. $L$ and $M$. Resting spores in oblique views showing the secondary valve mantle surrounded by an irregularly perforated collar

Chaetoceros spp. (A-F, I-M. MEB; G y H. MO) A-F. Chaetoceros compressus var. hirtisetus. A. Parte de una cadena degradada con una estatospora. Note que las valvas adyacentes no se tocan en los polos. B. Detalle de la estatospora de la fig. 5A. C y D. Estatospora en vista valvar y cingular respectivamente. E. Detalle del annulus de la estatospora de la fig. 5C. Note la ornamentación de la valva secundaria de la estatospora. F. Detalle de la fig. 5D mostrando la estructura delicada de la pared de la valva primaria de la estatospora. Note la empalizada de espinas del manto de esta valva. G-M. Chaetoceros contortus.

G. Parte de una cadena. Note las células giradas sobre el eje pervalvar (flechas), todas las células de contorno similar y las setas con parte basal oblicua, fusionadas en el borde de la colonia (flechas dobles). H-J. Valvas intercalares con setas gruesas, fuertemente silicificadas. Note en la fig. $5 \mathrm{H}$ las espinas complejas sobre la parte proximal de las setas. K. Detalle de la parte

distal de setas fuertemente silicificadas. Note la sección transversal circular y la presencia de espinas simples. L y M.

Estatosporas en vistas oblicuas mostrando la valva secundaria rodeada por un collar irregularmente perforado 

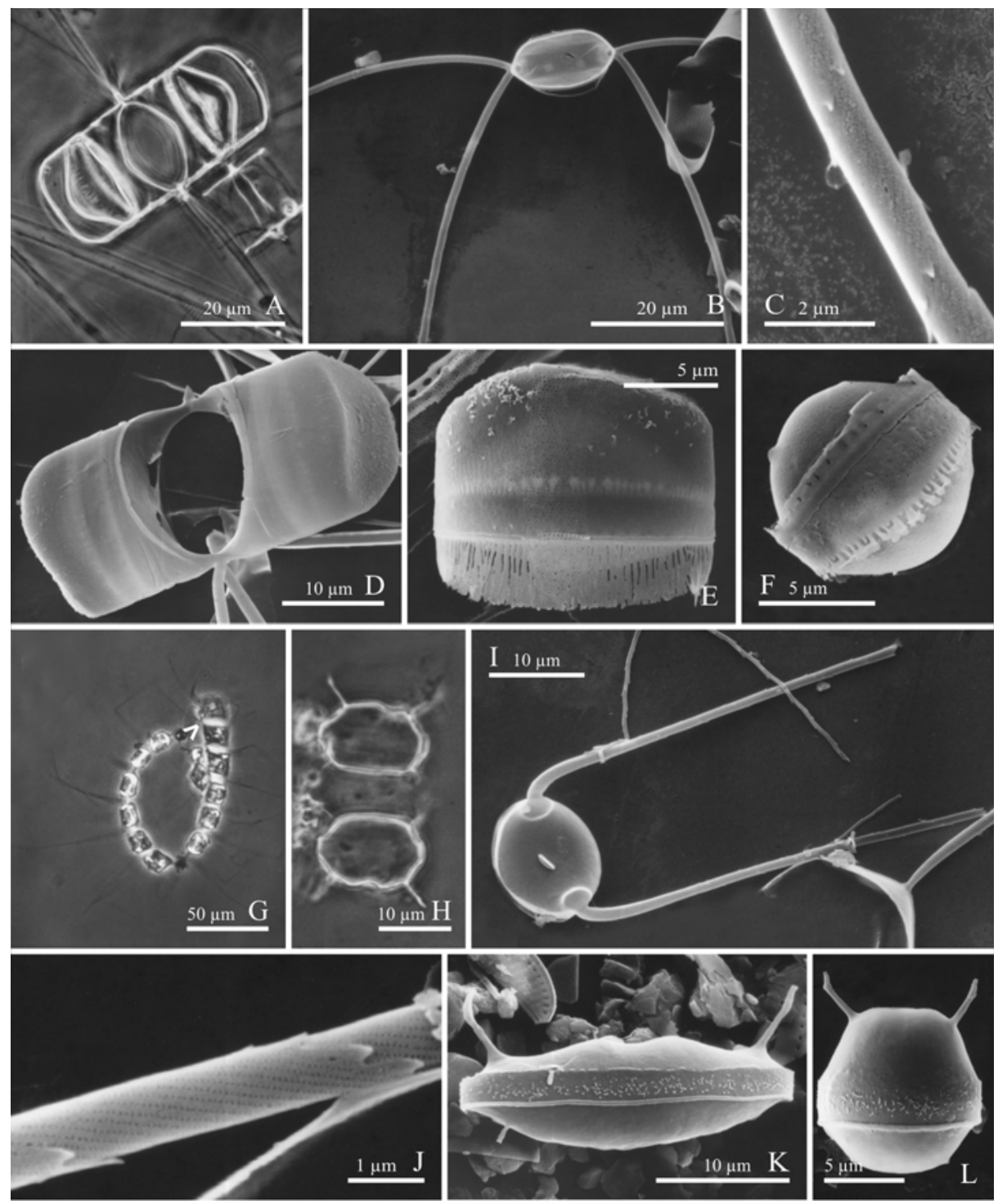

Figure 6

Chaetoceros spp. (A, G and H. LM; B-F, I-L. SEM) A-F. Chaetoceros curvisetus. A and D. Pairs of resting spores united by the valves of sibling cells and surrounded by a siliceous sheats to both abvalvar sides. $B$. Internal view of intercalary valve.

Note all the setae are curved towards the same side. C. Detail of the seta showing the spiraling rows of poroids and small spines. E. One resting spore with primary valve still covered by the siliceous sheat. F. Smooth resting spore with secondary valve mantle surrounded by a siliceous collar. G-L. Chaetoceros debilis. G. Chain. H. Part of chain with resting spores. I. Terminal valve in external view showing the central rimoportula. J. Detail of seta note the spiraling rows of poroids and small spines. $K$ and $L$. Resting spores of different outlines. Note the primary valve with two undulations and two rudimentary setae (or tubes) and the secondary convex valve

Chaetoceros spp. (A, G y H. MO; B-F, I-L. MEB) A-F. Chaetoceros curvisetus. A y D. Estatosporas pareadas unidas por las valvas de células vecinas rodeadas por vainas silíceas hacia ambos lados abvalvares. B. Vista interna de una valva intercalar. Note todas las setas curvadas hacia el mismo lado. C. Detalle de una seta mostrando las hileras longitudinales, secundariamente espiraladas de poroides y pequeñas espinas. E. Estatospora con la valva primaria aún cubierta por la vaina silícea. F. Estatospora lisa, con el manto de la valva secundaria rodeada por un collar silíceo. G-L. Chaetoceros debilis. G. Cadena. H. Parte de una cadena con estatosporas. I. Valva terminal en vista externa mostranto el rimoportula central. J. Detalle de una seta, note las hileras longitudinales, secundariamente espiraladas de poroides y pequeñas espinas. K y L. Estatosporas de diferentes morfologías. Note la valva primaria con gibas y dos setas rudimentarias (o tubos), y la valva secundaria convexa 
Chains curved and relatively long. Apertures wide and lanceolate, elliptical to almost circular (Fig. 6A, D). Cells rectangular in girdle view. One chloroplast per cell. Valves elliptical to almost circular (Fig. 6B). Mantle low. Sibling cells connected each other by corners of valves (Fig. 6A, D). Intercalary setae thinner than terminal ones, circular in cross-section, with minute spines and poroids arranged in spirals (Fig. 6C). All setae curved towards the same direction (Fig. 6B). Resting spores smooth, with valve mantle surrounded by siliceous filaments (Fig. 6F). Primary valve broadly convex to vaulted, secondary valve almost flat to convex (Fig. 6A, E, F). Resting spores originated in pairs united by valves of sibling cells with each primary valve covered by a siliceous sheat (Fig. 6A, $\mathrm{D}, \mathrm{E})$.

Measurements: apical axis, 8-24 $\mu \mathrm{m}$.

Distribution and abundance: Chaetoceros curvisetus has been frequently reported from the Argentinian Sea (Ferrario \& Galván 1989, Vouilloud 2003). During the present study this species was found throughout the year at all stations, rare.

\section{Chaetoceros debilis Cleve (Fig. 6G-L)}

Evensen \& Hasle 1975, p. 159, figs. 27-32; Hargraves 1979, p. 105, figs. 27-34; Hernández-Becerril 1996, p. 58, pl. 46, figs. 1-6, pl. 47, figs. 1-8; Jensen \& Moestrup 1998 , p. 36 , figs. $117-121$.

Chains long, curved and spiraly twisted (Fig. 6G). Apertures wide and rectangular to elliptical (Fig. 6G). Cells with one chloroplast. Frustules rectangular in girdle view (Fig. 6G). Valves elliptical. Valve surface flat or concave. Mantle low. Sibling cells not connected each other by corners of valves (Fig. 6G). Rimoportula slightly eccentric and oblique on terminal valves only (Fig. 6I). Setae circular, with the same pattern of spines and poroids as in C. curvisetus (Fig. 6J). Resting spores with dissimilar smooth valves (Fig. 6H, K, L). Primary valve with two undulations and two rudimentary setae (or tubes) close to the corners (Fig. 6K, L). Secondary valve convex (Fig. $6 \mathrm{~K}, \mathrm{~L})$.

Measurements: apical axis, 9-25 $\mu \mathrm{m}$.

Distribution and abundance: Chaetoceros debilis has been frecuently reported from the Argentinian Sea (Ferrario \& Galván 1989, Vouilloud 2003). During the present study this species appeared throughout the year at all stations, rare.

Remarks: Chaetoceros debilis is one of the species of the subgenus Hyalochaete that has been related to noxious events. Hargraves \& Maranda (2002) indicated that the species must be considered as potentially harmful because cell extracts of $C$. debilis can cause brachycardia in salmon smolts. Additionally, Smayda (2006) pointed out that blooms of C. debilis and C. wighamii in the Shetland Islands led to farmed salmon mortality.

\section{Chaetoceros decipiens Cleve (Fig. 7A-F)}

Brunel 1962, p. 99, pl. 21, figs. 1-4, pl. 22, figs. 1-5; Evensen \& Hasle 1975, p. 161, figs. 55-69; Hernández-Becerril \& Flores Granados 1998, p. 511, figs. 26-28; Jensen \& Moestrup 1998, p. 37, figs. 122-131.

Cells in long, straight chains (Fig. 7A). Apertures narrow to wide and elliptical (Fig. 7B-D). Four to ten chloroplasts per cell (Fig. 7A). Frustules rectangular in girdle view (Fig. 7A-D). Valves elliptical in outline. Valve surface concave with sharp corners (Fig. 7D). Mantle high. All setae long, thick, straight, with small spines and poroids arranged in longitudinal rows, becoming polygonal in cross-section (Fig. 7E, F). Sibling intercalary setae fused for a long distance, equivalent to several times their diameter, before diverging at an angle of $10-25^{\circ}$ from the chain axis (Fig. 7D, E). Terminal setae thicker than intercalary ones, diverging from cell corners and curving in $\mathrm{U}$ or $\mathrm{V}$, nearly parallel to the chain axis (Fig. 7A-C). Resting spores unknown.

Measurements: apical axis, 16-24 $\mu \mathrm{m}$.

Distribution and abundance: Chaetoceros decipiens has been frequently reported from the Argentinian Sea (Ferrario \& Galván 1989, Vouilloud 2003). During the present study this species was found throughout the year at all stations, rare.

Chaetoceros diadema (Ehrenberg) Gran (Fig. 7 G-K)

Hargraves 1972, p. 247, figs. 2-14; Hernández-Becerril 1996, p. 38, pl. 34, figs. 1-6, pl. 35, figs. 1-8; Jensen \& Moestrup 1998, p. 39, figs. $132-141$.

Basionym: Syndendrium diadema Ehrenberg (resting spore)

Synonyms: Chaetoceros distans var. subsecunda Grunow in Van Heurck

Chaetoceros subsecundus (Grunow) Hustedt.

Cells in chains. Apertures wide (Fig. 7I). Valve surface flat to concave. Mantle low. Intercalary setae thin and delicate (Fig. 7I). Resting spores with unequal valves with the surface covered by very tiny siliceous warts (Fig. 7GK). Primary valves with 4-12 long, strong and branched spines. Secondary valves convex, smooth.

Measurements: apical axis, 12-17 $\mu \mathrm{m}$.

Distribution and abundance: Chaetoceros diadema has 
been reported from the Argentinian Sea by Frenguelli (1939, as C. subsecundus), Ferrario et al. (1986), Gayoso (1999, 2001), and Romero \& Hensen (2002). During the present study we found resting spores free or in fragments of chains at Nueva Atlantis, Pinamar and Mar de Ajó in fall and winter.

\section{Chaetoceros didymus Ehrenberg (Fig. 8A-J)}

Rines \& Hargraves 1988, p. 77, figs. 154-163; HernándezBecerril 1991, p. 290, figs. 1-12; Jensen \& Moestrup 1998, p. 41, figs. 142-144, 146; Hernández-Becerril \& Flores Granados 1998, p. 511, figs. 37-39.

Synonyms: C. didymus var. anglica (Grunow) Gran

C. didymus var. protuberans (Lauder) Gran et Yendo

C. protuberans Lauder

Cells in straight chains (Fig. 8A). Apertures panduriform of variable size (Fig. 8A, D). Two chloroplasts per cell, each associated to one valve (Fig. 8A). Frustules rectangular in girdle view (Fig. 8A, D). Valves elliptical in outline (Fig. 8C). Valve surface with raised corners and a protuberance in the centre (Fig. 8D, E). Mantle low. Rimoportula flattened tube-like structure centrally located in the protuberance at terminal valves (Fig. 8E). Corners of valves and bases of setae with branched capilli, variable in size and density (Fig. 8E). All setae long, straight, coarse, and polygonal (four to seven-sided) in cross-section, perforated by poroids in uniseriate striae, and with spines at edges (Fig. $8 \mathrm{H}-\mathrm{J}$ ). Intercalary setae fusing at the margin or near the margin of the chain (Fig. $8 \mathrm{~A}, \mathrm{D}$ ), and diverging in acute angle in valvar plane (Fig. $8 \mathrm{C})$. Terminal setae directed towards the chain axis. Resting spores paired, united by thick setae (Fig. 8B, F, G). Primary valve smooth with one or two undulations, secondary valve flat, and aperture covered by a siliceous membrane.

Measurements: apical axis, 14-30 $\mu \mathrm{m}$.

Distribution and abundance: Chaetoceros didymus has been frecuently reported from the Argentinian Sea (Ferrario \& Galván 1989, Vouilloud 2003). During the present study this species was found throughout the year at all stations, rare.

Remarks: Chaetoceros didymus exhibits a considerable morphological variability, which has led to the proposal of numerous varieties such as $C$. didymus var. aggregata Mangin, C. didymus var. anglica (Grunow) Gran and C. didymus var. protuberans (Lauder) Gran \& Yendo. The latter might be a different and separate species (Hernández-Becerril, 1991), although some evidence, basically intergrades, indicates that both morphotypes are part of one and the same species (Hernández-Becerril \& Flores Granados 1998).

Chaetoceros filiferus Karsten (Fig. 9A, B)

Karsten 1907, p. 392, pl. 44, figs. 5a-b; Hernández-Becerril 1993b, p. 170, figs. 15-28; Hernández-Becerril \& Flores Granados 1998, p. 517, fig. 52.

Cells in delicate, long and straight or slightly twisted chains (Fig. 9A). Apertures narrow and elongate (Fig. 9B). Frustules rectangular in girdle view (Fig. 9A). Corners of intercalary valves not in contact each other, sibling setae fused far from the valve margins (Fig. 9B). All setae thin and fine, arising from inside the valve corners.

Measurements: apical axis, $14 \mu \mathrm{m}$.

Distribution and abundance: During the present study Chaetoceros filiferus was found in spring and summer at Pinamar and Santa Teresita stations, rare.

Remark: Chaetoceros filiferus is a new record for the South Western Atlantic.

\section{Chaetoceros laciniosus Schütt (Fig. 9C, D)}

Rines \& Hargraves 1988, p. 83, figs. 167-169; HernándezBecerril 1996, p. 38, pl. 30, figs. 1-6, pl. 31, figs 1-8; Jensen \& Moestrup 1998, p. 46, figs. 153-158.

Chains straight (Fig. 9C). Apertures very wide, square, rectangular or broadly elliptical, elongated in direction to the chain axis (Fig. 9C, D). One or two chloroplasts per cell. Frustules rectangular with raised corners in girdle view. Valve face slightly concave. Mantle low. Setae thin and long. Intercalary setae with long basal part, diverging almost perpendicular to the chain axis (Fig. 9C, D). Terminal setae with a short and straight base, curving smoothly in direction to the chain axis (Fig. 9D).

Measurements: apical axis, 8-16 $\mu \mathrm{m}$.

Distribution and abundance: Chaetoceros laciniosus has been reported from the Argentinian Sea by Marques Da Cunha \& Da Fonseca (1917), Frenguelli (1928), Hendey (1937), Frenguelli \& Orlando (1959), Balech (1964), and Carreto \& Verona (1974). During the present study this species was found from spring to fall at San Clemente del Tuyú, Las Toninas, La Lucila del Mar and Nueva Atlantis stations, rare.

Remarks: Chaetoceros laciniosus is probably conspecific with $C$. distans Cleve, in which case the latter name should have priority (Hernández-Becerril 1996). Chaetoceros pelagicus Cleve seems to be also conspecific with $C$. laciniosus however Jensen \& Moestrup (1998) pointed out that further investigations are needed before the taxon can be properly assigned to C. laciniosus. 

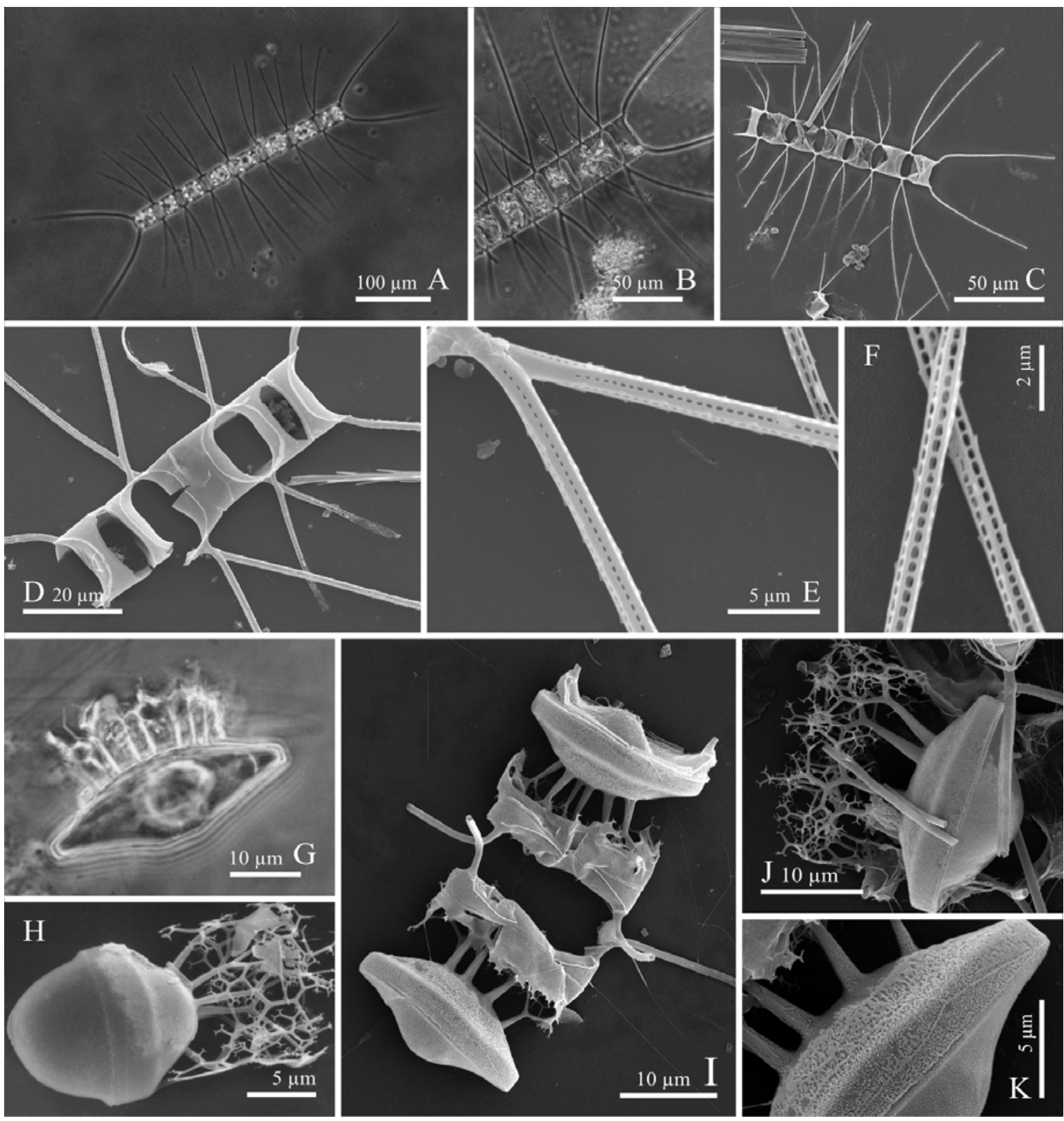

Figure 7

Chaetoceros spp. (A, B and G. LM; C-F, H-K. SEM) A-F. Chaetoceros decipiens. A-D. Whole chains or parts of chains. Note terminal setae thicker than the intercalary ones. E. Proximal part of the setae fused at the chain edge for a length equivalent to several times their diameter. F. Distal part of the setae showing quadrangular poroids and spines arranged in longitudinal rows. G-K. Chaetoceros diadema. G, H and J. Resting spores of different outlines with unequal valves. Note the crown of branched spines on the primary valve. I. Part of a chain with resting spores. K. Detail of fig. 7I showing the structure of the valve wall covered by very tiny siliceous warts

Chaetoceros spp. (A, B y G. MO; C-F, H-K. MEB) A-F. Chaetoceros decipiens. A-D. Cadenas enteras o partes de cadenas. Note las setas terminales más gruesas que las intercalares. E. Partes proximales de las setas fusionadas en el borde de la colonia por una longitud equivalente a varias veces su diámetro. F. Parte distal de setas mostrando poroides cuadrangulares y espinas ordenados en hileras longitudinales. G-K. Chaetoceros diadema. G, H y J. Estatosporas de diferentes morfologías con valvas desiguales. Note la corona de espinas ramificadas sobre la valva primaria. I. Parte de una cadena con estatosporas.

K. Detalle de la figura 7I mostrando la estructura de la pared de la valva cubierta por pequeños gránulos silíceos 

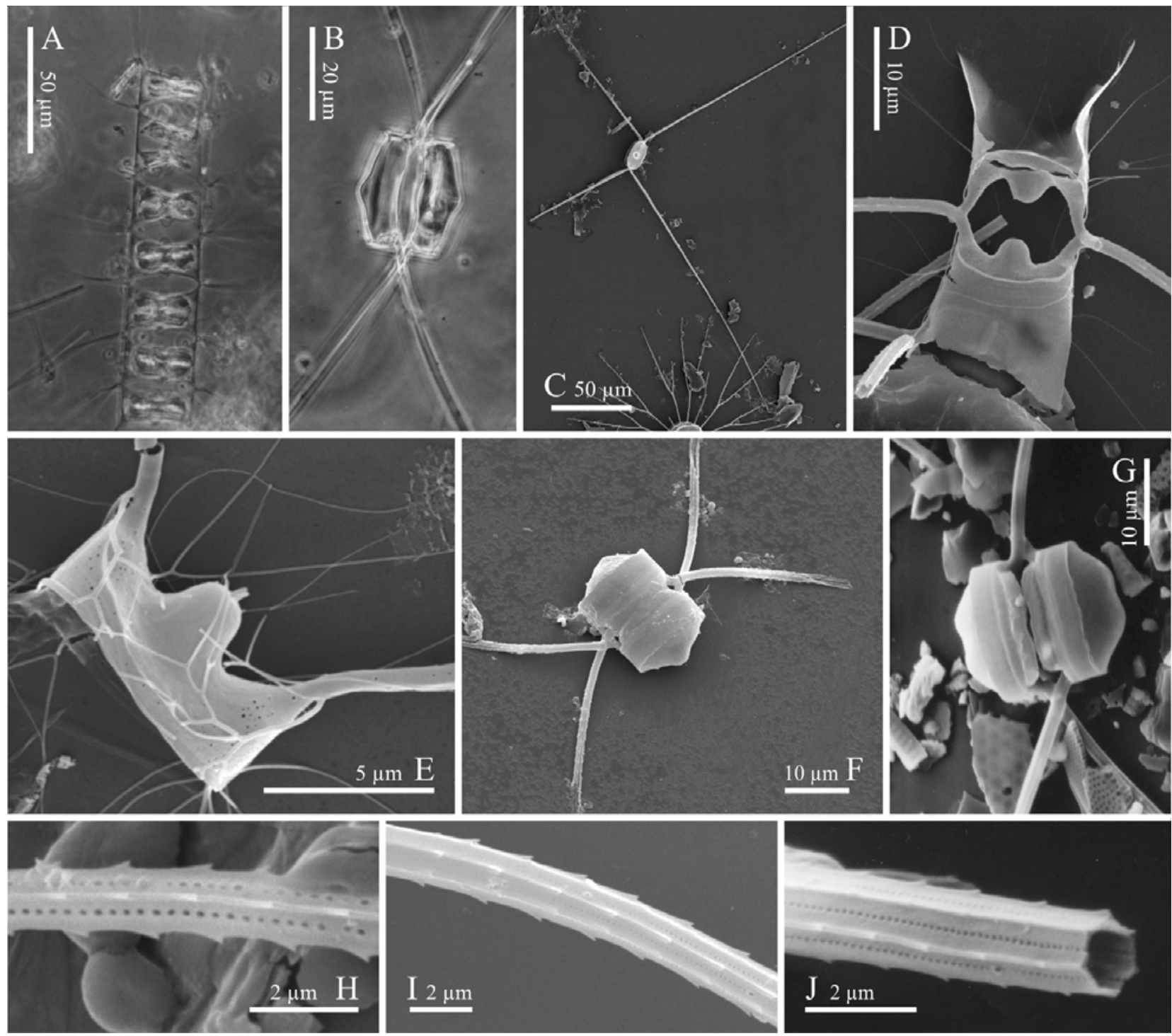

Figure 8

Chaetoceros didymus (A and B. LM; C-J. SEM). A. Part of a chain. B. Paired resting spores. C. Valves in valve view, note the orientation of the setae diverging in acute angle from the apical plane. D. Detail of a pair of sibling valves in girdle view showing the central protuberance, the panduriform aperture, the fusion of the setae at the margin of the chain and some delicate capilli. E. Terminal valve showing the external flattened tube of the rimoportula, well developed capilli and the structure of the valve wall with scattered poroids. F and G. Paired resting spores showing the aperture covered by a siliceous membrane. Note the different morphologies of the primary valves with one undulation (F) and with two undulations (G). H-J. Details of the setae polygonal (four to seven-sided) in cross-section showing the uniseriate longitudinal rows of poroids and the spines at the edges secondarily ordered in spirals

Chaetoceros didymus (A y B. MO; C-J. MEB). A. Parte de una cadena. B. Estatosporas pareadas. C. Valvas vecinas en vista valvar, note la orientación de las setas divergiendo en ángulo agudo del plano apical. D. Detalle de un par de valvas adyacentes en vista cingular mostrando la protuberancia central, la ventana panduriforme, las setas fusionadas en el margen de la cadena y algunos capilli. E. Valva terminal mostrando el tubo externo aplanado del rimoportula, capilli bien desarrollados y la estructura de la pared valvar con poroides esparcidos. F y G. Estatosporas pareadas mostrando la ventana cubierta por una membrana silícea. Note las diferentes morfologías de las valvas primarias con una ondulación (F) y con dos ondulaciones $(\mathrm{G})$.

H-J. Detalles de las setas, de sección transversal poligonal (cuatro a siete lados), mostrando hileras longitudinales uniseriadas de poroides y las espinas en las aristas secundariamente ordenadas en espirales 

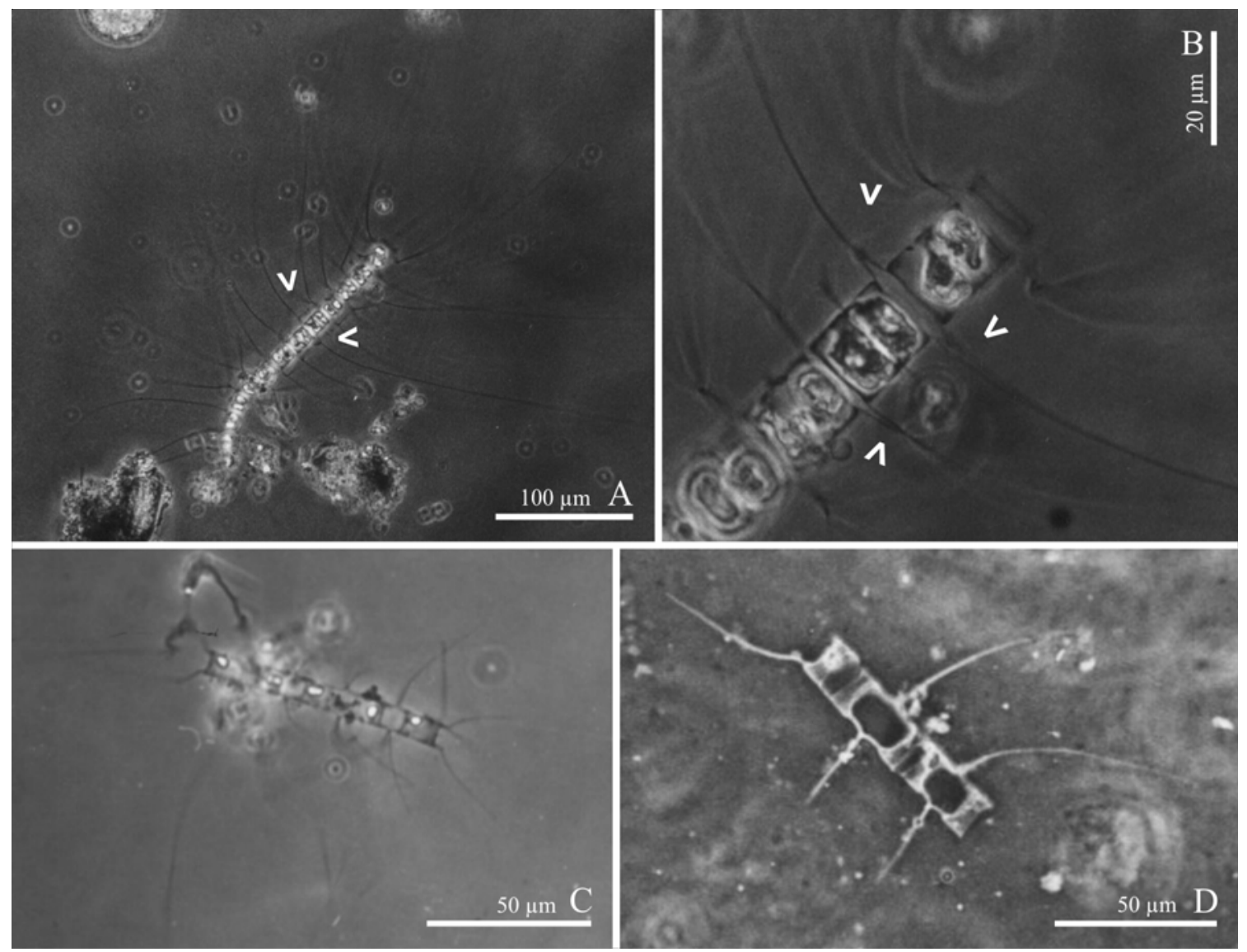

Figure 9

Chaetoceros spp. (LM) A and B. Chaetoceros filiferus. A. Part of a chain slightly twisted. B. Detail of the chain in fig. 9A showing the rectangular frustules and the setae of sibling cells fused far from the valve margins (arrowheads). C and D. Chaetoceros laciniosus. C. Whole chain. D. Part of a chain showing the rectangular apertures elongated in direction to the chain axis

Chaetoceros spp. (MO) A y B. Chaetoceros filiferus. A. Parte de una cadena levemente espiralada. B. Detalle de la cadena de fig. 9A mostrando frústulos rectangulares y las setas de células vecinas fusionadas lejos de los bordes valvares (flechas). C y D.

Chaetoceros laciniosus. C. Cadena completa. D. Parte de una cadena mostrando las ventanas rectangulares alargadas en sentido del eje de la colonia

Chaetoceros lauderi Ralfs in Lauder (Fig. 10A-F)

Hargraves 1979, p. 102, figs. 7-12; Rines \& Hargraves 1988, p. 84, figs. 170-173; Hernández-Becerril \& Flores Granados 1998, p. 511, fig. 35.

Cells in straight chains (Fig. 10A), slightly twisted about the chain axis. Apertures very narrow or absent (Fig. 10A). Many small chloroplasts per cell. Frustules long and cylindrical in girdle view (Fig. 10 A). Valves circular in outline (Fig. 10C). Valve face flat. Mantle low. All setae similar, originated from the corners of the valves (Fig. 10A), circular in cross-section, with both poroids and rows of minute spines arranged in spirals (Fig. 10D). Intercalary setae almost perpendicular to the chain axis, diverging in acute angles to the valvar plane (Fig. 10A, C). Terminal setae in $\mathrm{U}$ shape, directed to the chain axis (Fig. 10A). Resting spores with unequal valves (Fig. 10E). Primary valve strongly convex or even capitate, covered by conspicuous spines and surrounded by a marginal ring of spines (Fig. 10B, E, F). Secondary valve less convex, with a marginal ring of less strong spines becoming filamentlike distally (Fig. 10E).

Measurements: apical axis, 15-25 (38) $\mu \mathrm{m}$.

Distribution and abundance: Chaetoceros lauderi has been reported from the Argentinian Sea by Marques Da Cunha \& Da Fonseca (1917), Charpy \& Charpy (1977) and Balech (1979). During the present study this species was found in August 2000 at all stations, very rare. 

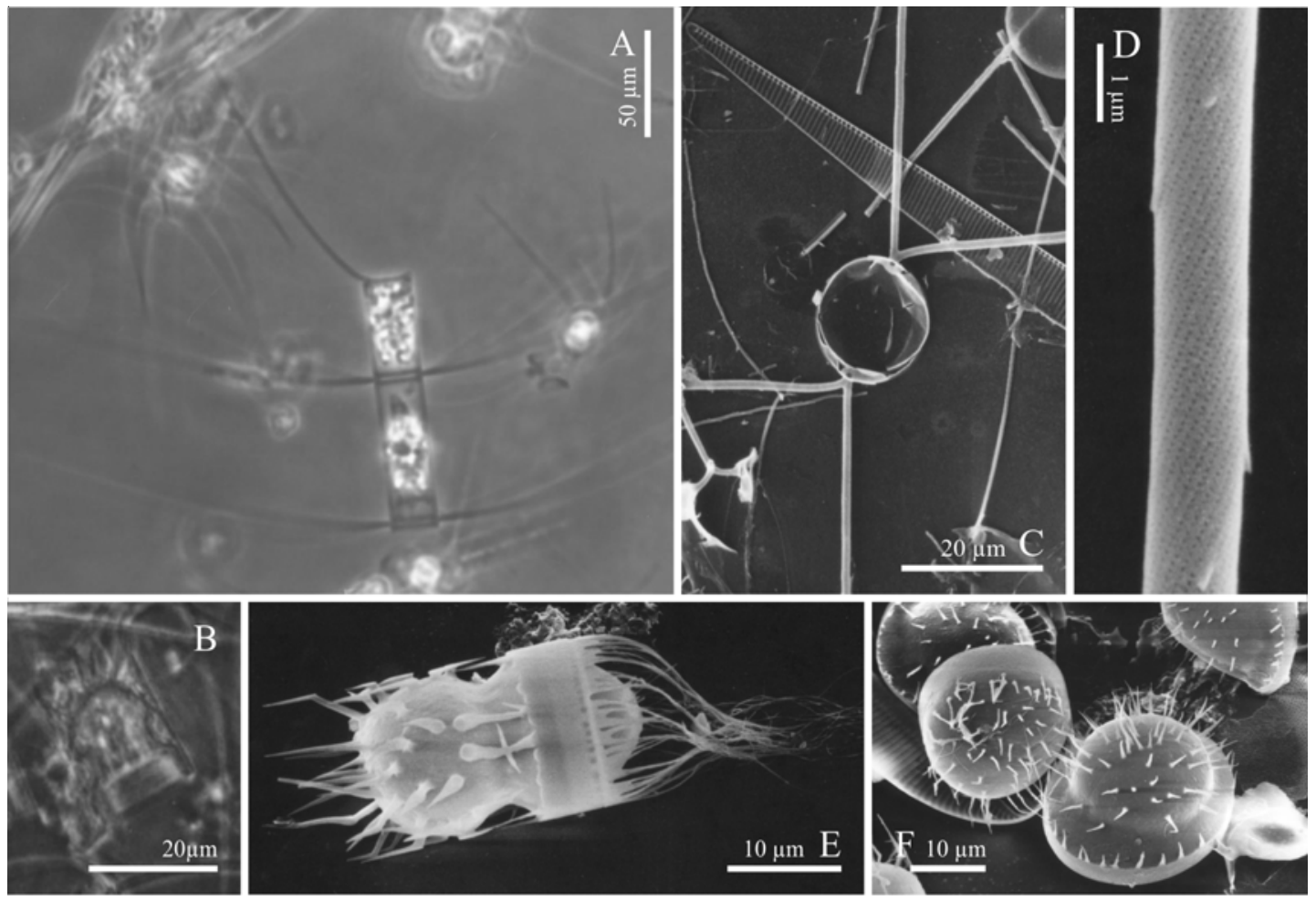

Figure 10

Chaetoceros lauderi (A and B. LM; C-F. SEM). A. Part of a chain. Note the narrow almost absent apertures. B and F.

Primary valves of resting spores showing different morphologies, capitate to strongly vaulted, covered with spines. C. Pair of sibling valves in valve view, showing the circular valve outline and the orientation of the setae. D. Detail of a seta with rows of poroids and minute spines arranged in spirals. E. Resting spore with capitate primary valvecovered with large spines and convex secondary valve smooth. Note the marginal ring of spines on both valve mantles, more evident on the secondary valve

Chaetoceros lauderi (A y B. MO; C-F. MEB). A. Parte de una cadena. Note las ventanas muy angostas casi ausentes. B y F. Valvas primarias de estatosporas de diferentes morfologías, capitadas a fuertemente abovedadas, cubiertas por espinas. C. Par de valvas adyacentes en vista valvar, mostrando el contorno valvar circular y la orientación de las setas. D. Detalle de una seta con poroides y pequeñas espínulas ordenadas en hileras longitudinales secundariamente espiraladas. E. Estatospora con valva primaria capitada cubierta por espinas grandes y valva secundaria convexa lisa. Note el anillo marginal de espinas sobre ambos mantos valvares, más evidentes en la secundaria

Remarks: Chains and cells of Chaetoceros lauderi are very similar to $C$. teres Cleve, but both species are distinguished by the morphology of resting spores (Hargraves 1979). Distribution of both species also appears to be different, with C. lauderi distributed in warm to temperate waters whereas $C$. teres is distributed in temperate to cold waters in the North Hemisphere (Hasle \& Syvertsen 1996, Hernández-Becerril \& Flores Granados 1998).

\section{Chaetoceros lorenzianus Grunow (Fig. 11A-F)}

Rines \& Hargraves 1988, p. 85, figs. 178-184; Hasle \& Syvertsen 1996, p. 204, pl. 42; Jensen \& Moestrup 1998, p. 48 , figs. $160-165$.
Chains straight of variable length (Fig. 11A, B). Apertures wide, lanceolate to elliptical (Fig. 11A-C). Numerous small chloroplasts (4-10) per cell. Frustules rectangular in girdle view (Fig. 11A, B). Valve elliptical in outline. Valve face flat or concave (Fig. 11C). Mantle low. Setae long, thick, polygonal in cross-section, with big poroids and spines in longitudinal rows (Fig. 11C, D). Intercalary setae arising from the corners of valves, fusing near the chain margin, perpendicular or diverging in an angle of $20-45^{\circ}$ to the axis chain (Fig. 11C). Terminal setae $U$ shaped, directed towards the chain axis (Fig. 11A, B). Resting spores with dissimilar valves (Fig. 11B, E, F). Primary valve with two high apical and conical protuberances and two branching spines. Secondary valve smooth with one or two low undulations. 

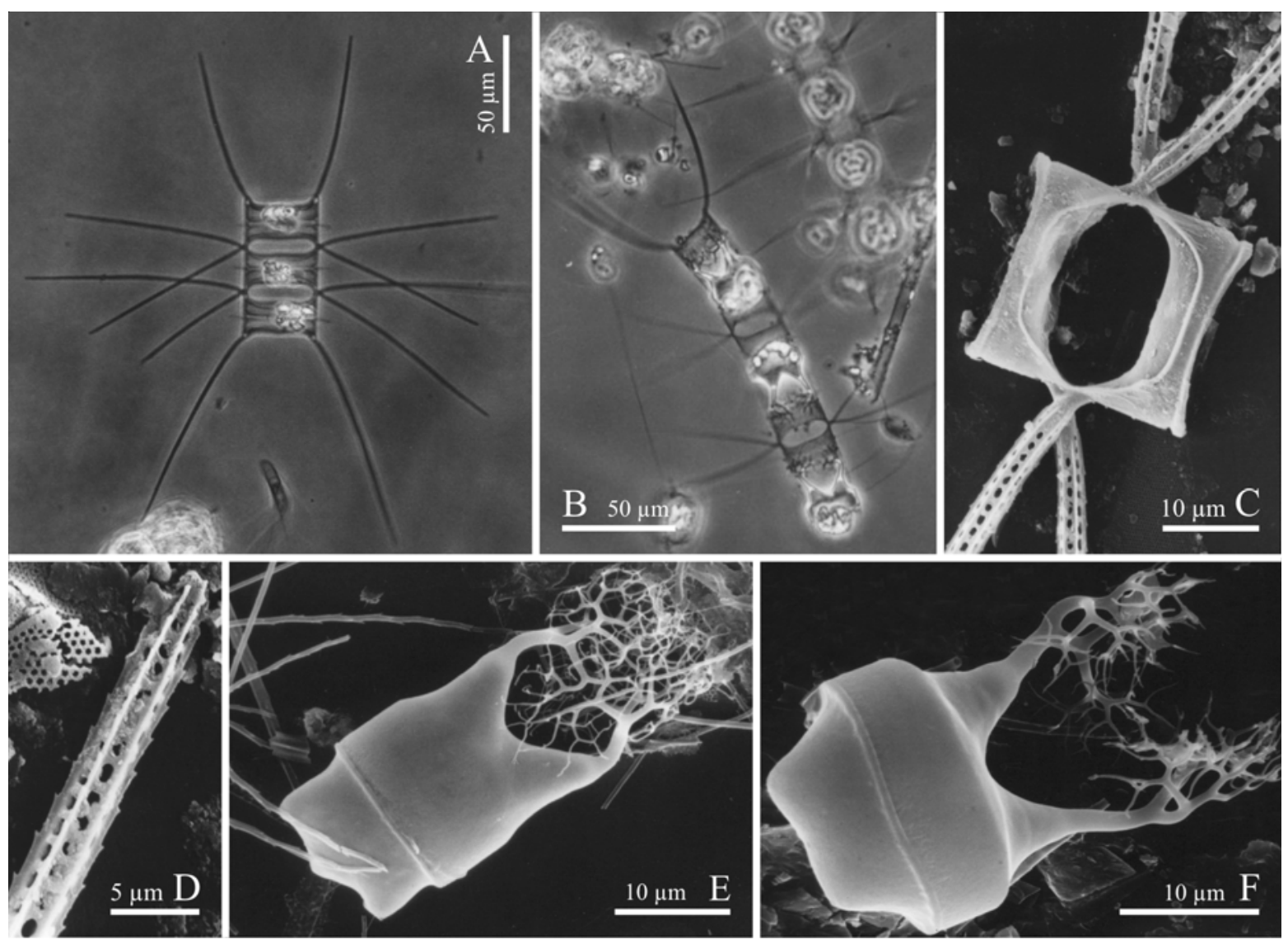

Figure 11

Chaetoceros lorenzianus (A and B. LM; C-F. SEM) A. Short chain. B. Part of a chain with resting spores. C. Pair of sibling valves in girdle view showing the intercalary setae arising from the corners of valves, fusing just near the chain margin. D. Tip of a seta. E and F. Resting spores of different morphologies showing the primary valve with two protuberances and two branching spines and the secondary valve smooth with one or two low undulations

Chaetoceros lorenzianus (A y B. MO; C-F. MEB) A. Cadena corta. B. Parte de una cadena con estatosporas. C. Par de valvas vecinas en vista cingular mostrando setas intercalares originadas en los polos de las valvas, fusionadas justo en el margen de la colonia. D. Extremo de una seta. E y F. Estatospora de diferentes morfologías mostrando la valva primaria con dos protuberancias y dos espinas ramificadas y la valva secundaria lisa con una o dos ondulaciones bajas

Measurements: apical axis, $16-36 \mu \mathrm{m}$.

Distribution and abundance: Chaetoceros lorenzianus has been frequently reported from the Argentinian Sea (Ferrario \& Galván 1989, Vouilloud 2003). During the present study this species was found throughout the year at all stations, rare.

Remarks: Chaetoceros lorenzianus is harmful blooms species associated with mass mortality of anchovies in the Gulf of Nicoya, Costa Rican Pacific (Vargas-Montero \& Freer 2004a, b).

\section{Chaetoceros radicans Schütt (Fig. 12A-F)}

Fryxell \& Medlin 1981, p. 8, figs. 9-15, 29-42, 51;
Stockwell \& Hargraves 1986, p. 86, figs. 22-27; Koch \& Rivera 1988, p. 113, figs. 27-34, 39; Rines \& Hargraves 1988, p. 90, figs. 192-198; Hernández-Becerril 1996, p. 58, pl. 48 , figs. 1-6, pl. 49 , figs. 1-7.

Cells in chains. Valves elliptical in outline (Fig. 12A, B). Intercalary setae with long capilli and spines of variable length and density, arranged in spirals or irregular pattern, fused in the margin of the chain, curved in an angle of $90^{\circ}$ regarding the apical axis (Fig. 12A, B). Resting spores in pairs, joined by a 'basal plate', with smooth setae curving and bending around the valves paired (Fig. 12C, D). Primary valve convex or flat with a central protuberance, smooth or with papillae or costae (Fig. 12D, E). Secondary valve flat and smooth (Fig. 12E). 

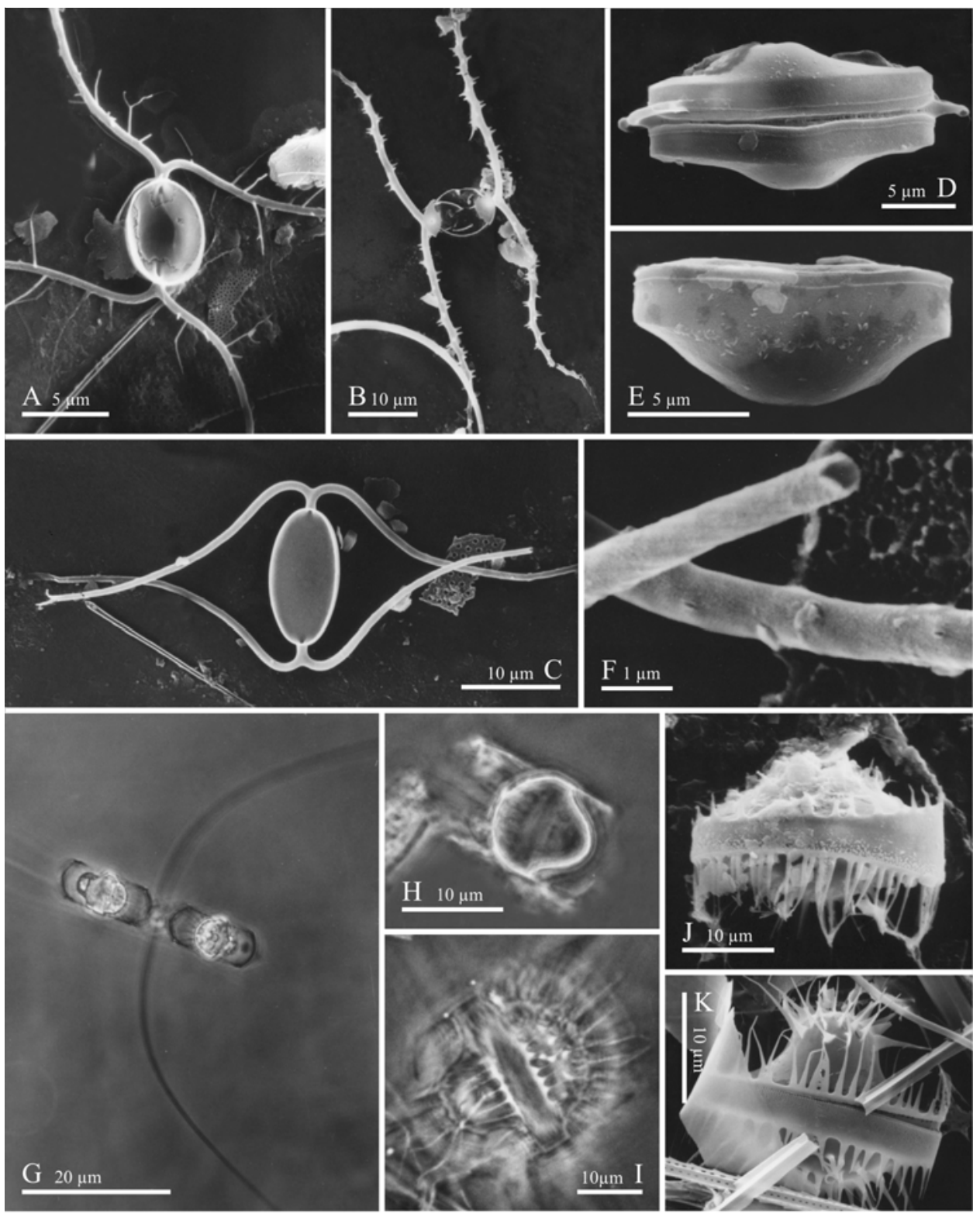

Figure 12

Chaetoceros spp. (A-F, J and K. SEM; G-I. LM). A-F. Chaetoceros radicans. A and B. Pairs of sibling valves showing the setae diverging in angles of $9^{\circ}$ from the apical plane, almost parallel or diverging from the transapical plane, with well developed capilli or strong spines in spiral rows. C. Basal plate of paired resting spores in valve view. Note the orientation of the setae. D. Paired resting spores. E. Resting spore, note the primary valve with a central protuberance and secondary valve flat. $F$. Detail of the setae showing the spiraling striation pattern and the circular cross-section. G-K. Chaetoceros seiracanthus. G. Part of a chain with resting spores. H-K. Resting spores of different morphologies with valves covered with spines and mantle surrounded by a palisade of spines

Chaetoceros spp. (A-F, J y K. MEB; G-I. MO). A-F. Chaetoceros radicans. A y B. Pares de valvas adyacentes mostrando las setas divergentes en ángulo de $90^{\circ}$ respecto del plano apical, casi paralelas o divergentes en el plano transapical, con capilli bien desarrollados o espinas robustas ordenadas en hileras espiraladas. C. Placa basal de un par de estatosporas pareadas en vista valvar. Note la orientación de las setas. D. Estatosporas pareadas. E. Estatospora, note la valva primaria con una protuberancia central y la valva secundaria plana. F. Detalle de las setas mostrando el patrón de estriación espiralado y la sección transversal circular. G-K. Chaetoceros seiracanthus. G. Parte de una cadena con estatosporas. H-K. Estatosporas de diferentes morfologías con valvas cubiertas por espinas y manto rodeado por una empalizada de espinas 
Measurements: apical axis, 6-14 $\mu \mathrm{m}$.

Distribution and abundance: Chaetoceros radicans has been reported from the Argentinian Sea by Frenguelli \& Orlando (1959), Balech (1978) and Romero \& Hensen (2002). During the present study this species appeared from summer to winter at Nueva Atlantis, Mar de Ajó, Pinamar and Villa Gesell, rare.

Remarks: Chaetoceros cinctus Gran and C. furcellatus Bailey are species closely related to $C$. radicans regarding their resting spores. However, vegetative cells of $C$. radicans may be distinguished of both mentioned species by presenting capilli at the intercalary setae.

\section{Chaetoceros seiracanthus Gran (Fig. 12G-K)}

Rines \& Hargraves 1988, p. 92, fig. 199; Jensen \& Moestrup 1998, p. 53, figs. 191-200.

Cells in chains (Fig. 12G). One chloroplast per cell. Valves of sibling cells not touching each other at the corners. Setae thin arising from inside chain margin. Resting spores located in the centre of the vegetative cells (Fig. 12G, H). Primary valve strongly convex to domed, covered in the centre by spines of different length and surrounded in the valve margin by spines or filaments of variable length (Fig. 12I-K). Secondary valve rounded to capitate, also with spines and the marginal ring of spines or filaments (Fig. 12I-K).

Measurements: apical axis, 11-28 $\mu \mathrm{m}$.

Distribution and abundance: Chaetoceros seiracanthus has been reported from Argentina by Balech (1964), Ferrario et al. (1986) and Frenguelli (1935). During the present study resting spores of this species were found in fall and winter at San Clemente del Tuyú, Pinamar and Mar de Ajó stations, rare.

\section{Chaetoceros socialis Lauder (Fig. 13A-H)}

Evensen \& Hasle 1975, p. 160, figs. 33-39; HernándezBecerril 1996, p. 63, pl. 50, figs. 1-6, pl. 51, figs. 1-8; Jensen \& Moestrup 1998, p. 56, figs. 207-215.

Cells in short and curved, delicate chains, joined by long centrally oriented setae in irregular globose colonies embedded in mucilage (Fig. 13A, B). Apertures hexagonal relatively wide (Fig. 13H). One chloroplast per cell. Frustules rectangular, in girdle view (Fig. 13A). Intercalary valves not touching each other. Valves elliptical in outline (Fig. 13C-F). Setae delicate, thin and long, with spiral rows of small spines (Fig. 13D-G). Some valves present three intercalary curved setae with spines, and one longer, straight, with (Fig. 13F, G)or without spines (Fig. 13D). Resting spores with both valves convex, generally paired, joined by setae (Fig. 13H). Primary valve with processes or costae in the centre. Secondary valve smooth.

Measurements: apical axis, 6-12.5 $\mu \mathrm{m}$.

Distribution and abundance: Chaetoceros socialis has been reported from the Argentinian Sea (Ferrario \& Galván 1989, Vouilloud 2003, Negri et al. 2004). During the present study this species was found common in fall of 2000 at all stations, and was rare throughout the year at all stations.

Remarks: The long straight setae directed towards the centre of the globose colonies have been traditionally described as smooth, without spines or any other ornamentation. In this study we have observed some colonies with all setae, including those directed to the centre, having tiny spines arranged in spiral rows along their entire length (Fig. 13F, G). The morphology of the resting spores is very variable with convex valves or with one valve convex and the other more flattened, both smooth or ornamented with spines or costae. C. socialis has been cited as a harmful species, associated to the production of mucilage, causing clogging of gills and anoxia in fishes and benthic organisms during its blooms. The species developed intense and large blooms in the area of Chiloé, Chile, and that the blooms occasionally affected cultured fish appetite (Clément \& Lembeye 1993).

Chaetoceros subtilis var. abnormis Proschkina-Lavrenko (Fig. 14A-N)

Proschkina-Lavrenko \& Makarova 1968, p. 181; Rines \& Hargraves 1988, p. 96, figs. 205, 206; Hasle \& Syvertsen 1996, p. 219; Jensen \& Moestrup 1998, p. 58; Aké-Castillo et al. 2004, p. 204, figs. 2b, 4.

Synonyms: Chaetoceros apendiculatus Müller-Melchers

\section{Chaetoceros atlantidae Müller-Melchers}

Cells solitary or in short (up to 6 cells per chain), straight to curved chains (Fig. 14A-G). No apertures (Fig. 14A, B). One or two chloroplasts per cell. Frustules longer (pervalvar axis) than wider, heteropolar, with «anterior» convex valves and «posterior» concave valves, which fit one in the other in the chains. Valves elliptic to circular in outline (Fig. 14H, J-L), smooth with small poroids spread at random (Fig. 14I, K). In the posterior valve there is a rim dividing the valve face from the mantle (Fig. 14K, L), and occasionally another irregular rim on the valve face (Fig. 14K). Rimoportula subcentrally located on anterior valves (Fig. 14H-J) and on posterior terminal valves (not observed). Setae on anterior terminal valves and intercalary valves thin with small spines in spirals (Fig. 14M). Posterior terminal valves with only 

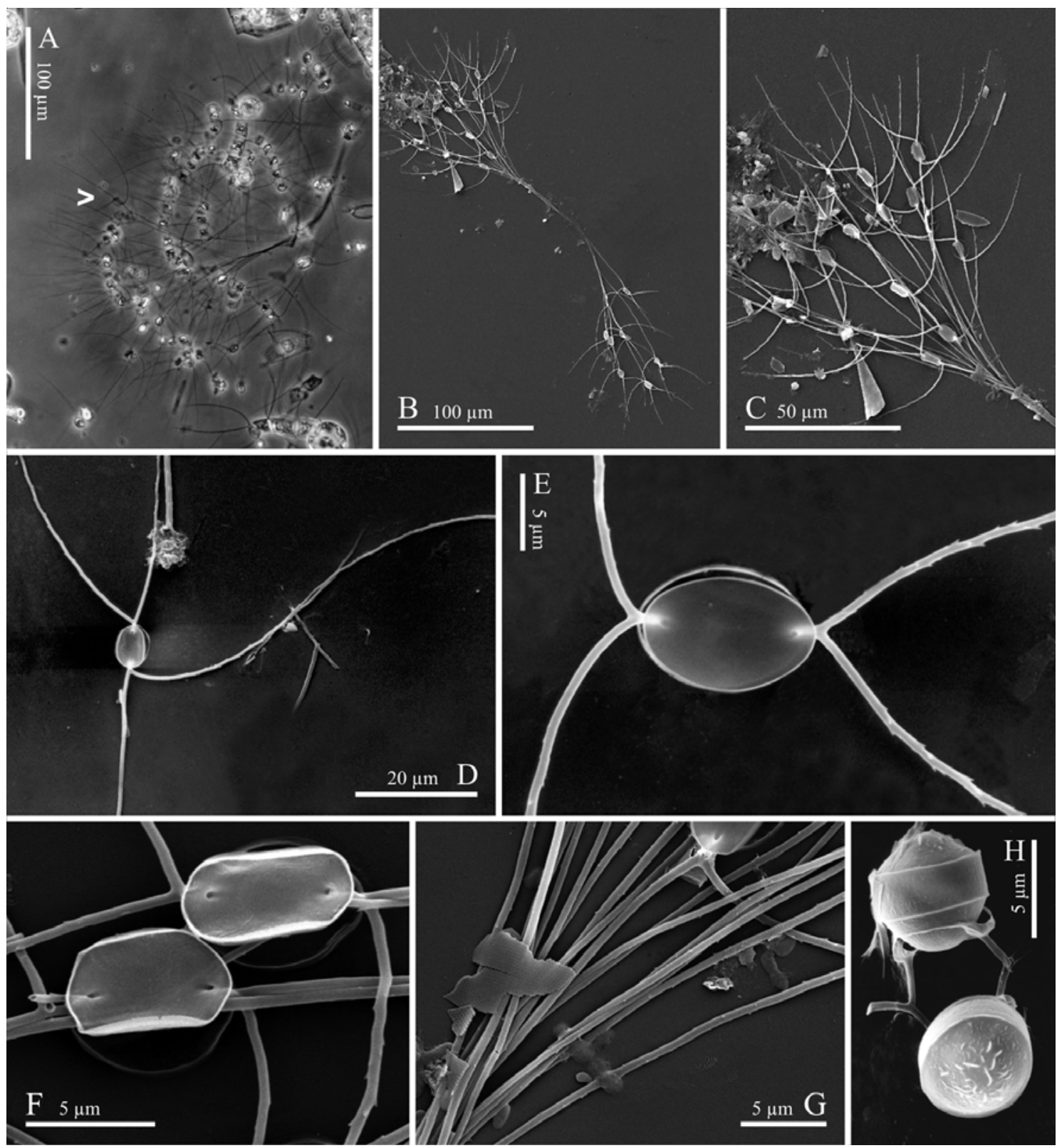

Figure 13

Chaetoceros socialis (A. LM; B-H. SEM). A and B. Short chains united by the long centrally oriented setae. C. Part of colony of fig. B. Note all the setae curved outwards of the colony except for those long straight centrally oriented. D and

E. Pairs of sibling valves with one straight seta and three common setae (D) and with four common setae (E). Note the absence of spines on the straight centrally oriented seta on fig. 13D. F. Details of valves in internal view showing all the setae with spiraling rows of small spines. G. Detail of the bunch of straight setae near the center of the colony. Note the presence of small spines along the setae. $\mathrm{H}$. Resting spores

Chaetoceros socialis (A. MO; B-H. MEB). A y B. Cortas cadenas unidas por largas setas orientadas hacia el centro. C. Parte de la colonia de fig. 13B. Note todas las setas orientadas hacia afuera de la colonia con excepción de las setas largas rectas orientadas hacia el centro. D y E. Pares de valvas adyacentes con una seta recta y tres setas comunes (D) y con cuatro setas comunes (E). Note la ausencia de espinas en la seta recta orientada hacia el centro en la fig. 13D.

F. Detalles de valvas en vista interna mostrando todas las setas con hileras espiraladas de espinas diminutas.

G. Detalle de un ramillete de setas rectas cerca del centro de la colonia. Note la presencia de espinas diminutas a lo largo de las setas. H. Estatosporas 

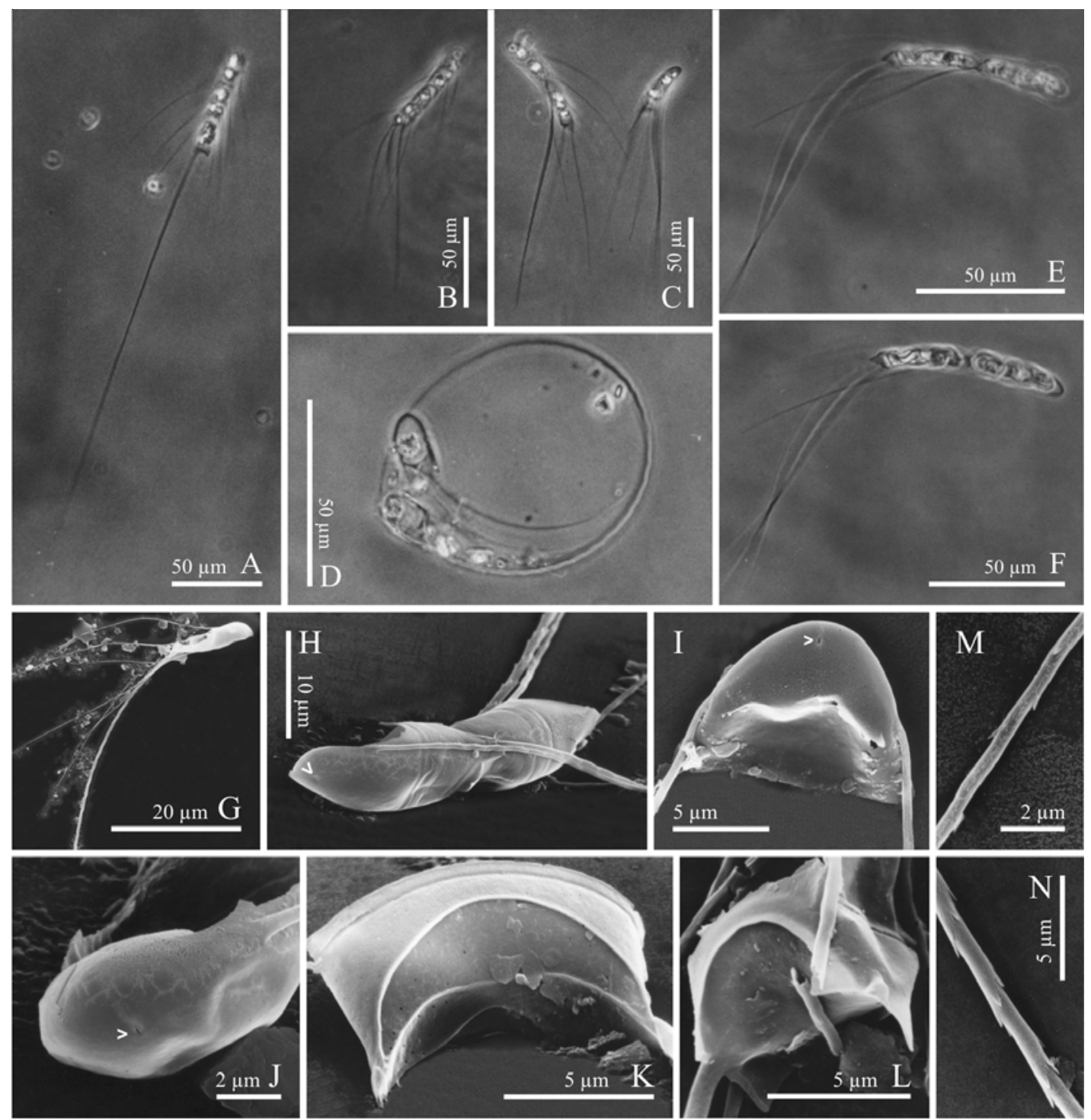

Figure 14

Chaetoceros subtilis var. abnormis (A-F. LM; G-N. SEM). A. Chain of five cells, showing the posterior terminal valve with one coarse seta. Note the absence of apertures among the frustules. B-G. Chains with different numbers of cells in narrow and oblique girdle view. D. Two cells with curved setae. E and F. Same chain in different focuses. G. Note the differences among the thin setae and the coarse one. H. Colony seen from the anterior end. Arrow indicates the external aperture of the rimoportula on the anterior valve. I. Anterior terminal valve in broad girdle view, note the smooth valve wall, the

insertion of the setae and the external aperture of the rimoportula. J. Detail of the external aperture of the rimoportula (arrowhead) of the valve of fig. 14H. K and L. Posterior terminal valves with one setae showing the conspicuous ridge between valve face and mantle. Note in fig. $14 \mathrm{~K}$ the additional irregular ridge on valve face.

$M$ and $N$. Details of thin and coarse setae respectively. Note the absence of poroids on both types of setae

Chaetoceros subtilis var. abnormis (A-F. MO; G-N. MEB). A. Cadena de cinco células en vista cingular ancha, mostrando la valva terminal posterior con una única seta gruesa. Note la ausencia de ventanas entre frústulos. B-G. Cadenas con diferente número de células en vistas cingulares angosta y oblicua. D. Dos células con setas curvadas. E y F. Misma cadena en diferentes focos. G. Note las diferencias entre las setas finas y la gruesa. H. Colonia vista desde el extremo anterior. La flecha indica la abertura externa del rimoportula de la valva anterior. I.

Valva terminal anterior en vista cingular ancha, note la pared valvar lisa, la inserción de las setas y la abertura externa del rimoportula. J.

Detalle de la abertura externa del rimoportula (flecha) de la valva de fig. 14H. K y L. Valvas terminales posteriores con una sola seta mostrando la conspicua costilla entre la superficie valvar y el manto. Note en fig. 14K la costilla irregular adicional sobre la superficie valvar. M y N. Detalles de las setas fina y gruesa respectivamente. Note la ausencia de poroides en ambos tipos de setas 
one terminal thicker seta with large spines in spirals (Fig. $14 \mathrm{~N})$. All setae directed towards the posterior end of the chain or cell, almost parallel to the chain axis (Fig. 14A-G).

Measurements: apical axis, 6-11.5 $\mu \mathrm{m}$, pervalvar axis, 30$37 \mu \mathrm{m}$.

Distribution and abundance: Chaetoceros subtilis var. abnormis has been reported from the Argentinian Sea in front of Necochea by Müller Melchers (1955, as Ch. apendiculatus Müller Melchers) and from Bahía Blanca estuary by Gayoso (1999). During the present study this variety was scarce all year round, only common in October 1999 and May 2000, at all stations.

Remarks: The shape of the solitary cells or chains is characteristic of this species as well as its relative fragility. The evident heteropolarity and the presence of posterior terminal valves with only one thick setae, the other absent or almost reduced, are additional morphological characters to distinguish this taxon. Rines \& Hargraves (1988) showed specimens with resting spores from Narraganset Bay, which were not found in our study. Chaetoceros subtilis var. abnormis f. simplex ProschkinaLavrenko, is a closely related taxon, but differs by having only one seta per cell (Marino et al. 1991, Aké-Castillo et al. 2004).

There are few records of Chaetoceros subtilis var. abnormis all over the world: the Black Sea, Azov Sea, Narraganset Bay and Laguna Sontecomapan, México (Aké-Castillo et al. 2004), in fjords of Denmark (Jensen \& Moestrup 1998), coasts of Uruguay (Burone \& Bayseé 1985) and from the littoral off Brazil (Torgan et al. 1999, Procopiak et al. 2006). The material examined here is much similar to the species Chaetoceros atlantidae and C. apendiculatus described by Müller-Melchers (1953) from coastal waters of Uruguay, an area close to the area of the current studied material.

\section{Concluding remarks}

A total of 20 taxa of the genus Chaetoceros were found in Buenos Aires coastal waters, 3 species belong to the subgenus Chaetoceros (Phaeoceros) and 17 taxa to the subgenus Hyalochaete. Chaetoceros filiferus and Chaetoceros compressus var. hirtisetus are recorded for the first time for the South Western part of the Atlantic Ocean.

Most taxa appeared sporadically in all field stations and we found no considerable differences in the spatial distribution of the species. Chaetoceros lorenzianus, $C$. didymus, C. decipiens, C. curvisetus and C. debilis were recorded most frequently. $C$. rostratus was found very rarely. Only resting spores of Chaetoceros diadema and
C. seiracanthus were recorded.

Some of the species found in coastal waters off Buenos Aires have a cosmopolitan distribution: C. danicus, $C$. affinis, C. contortus, C. curvisetus, C. debilis, C. decipiens, C. diadema, $C$. radicans and $C$. socialis. Other species are typically characteristic for warm to temperate waters, like $C$. peruvianus, $C$. rostratus, $C$. didymus, $C$. filiferus, C. lauderi, C. lorenzianus and $C$. seiracanthus. The distribution of $C$. subtilis var. abnormis, a very delicate taxon that has been reported only in a few occasions, could not been determined, however, considering the information reported by Burone \& Bayseé (1985), Rines \& Hargraves (1988), Jensen \& Moestrup (1998), Torgan et al. (1999), Aké-Castillo et al. (2004), Procopiak et al. (2006), Gogorev et al. (2006, as C. abnormis), and our own data we think that $C$. subtilis var. abnormis posibly is a cosmopolitan species.

From all the species considered to be potentially harmful, we only found Chaetoceros danicus, C. debilis, $C$. lorenzianus and C. socialis. The three former have been related to mass fish mortality along the western coast of the USA, the Shetland Islands and Costa Rica, respectively (Horner et al. 1997, Smayda 2006, VargasMontero \& Freer 2004a, b), and the latter C. socialis, which produces mucilaginous colonies, has been linked to harmful events in fish cultures off southern Chile (Clément \& Lembeye 1993, Smayda 2006). None of these species were documented to cause any nuisable effect during this study.

\section{Acknowledgments}

We thank Dr. Silvia Sala and Dr. Nora Maidana for critical review of the manuscript. Corrections made by two anonymous reviewers greatly improved our manuscript. The electron microscopy was done in the Servicio de Microscopía Electrónica of the Facultad de Ciencias Naturales y Museo. The research was supported by grants from the CONICET, PIP 0525/98 and PIP 5312/05.

\section{Literature cited}

Aké-Castillo JA, SL Guerra-Martínez \& ME ZamudioReséndiz. 2004. Observations on some species of Chaetoceros (Bacillariophyceae) with reduced number of setae from a tropical coastal lagoon. Hydrobiologia 524: 203-213.

Anonymous. 1975. Proposals for standardization of diatom terminology and diagnosis. Nova Hedwigia, Beiheft 53: 323-354.

Balech E. 1964. El plancton de Mar del Plata durante el período 1961-1962. Boletín del Instituto de Biología Marina 4: 149. 
Balech E. 1976. Fitoplancton de la Campaña Convergencia 1973. Physis, Sec. A. 35: 47-58.

Balech E. 1978. Microplancton de la Campaña Productividad IV. Revista del Museo Argentino de Ciencias Naturales 'Bernardino Rivadavia', Hidrografía 5: 137-201.

Balech E. 1979. Dinoflagelados. Campaña Oceanográfica Argentina, Islas Orcadas, 06/75. Servicio de Hidrografía Naval, Buenos Aires. Publicaciones Técnicas Oceanográficas H 655: 1-76.

Brunel J. 1962. Le phytoplancton de la Baie des Chaleurs. Contributions du Ministère de la Chasse et des Pêcheries, Montreal 91: 1-365.

Brunel J. 1966. Normalisation de la terminologie des soie dans le genre Chaetoceros. Naturaliste Canadien 93: 849-860.

Brunel J. 1972. Orientation of setae in the genus Chaetoceros in regard to the apical axis. Journal of the Marine Biological Association of India 14: 315-327.

Burone FS \& C Bayssé. 1985. Diatomeas de la Bahía de Maldonado (Uruguay). II. Biddulphiaceae y Chaetoceraceae. Contribuciones del Departamento de Oceanografía, Facultad de Humanidades y Ciencias, Universidad de la República, Montevideo 2: 1-31.

Carreto JI \& CA Verona. 1974. Fitoplancton, pigmentos y condiciones ecológicas del Golfo San Matías I. Campaña SAO I (Marzo 1971). Instituto de Biología Marina de Mar del Plata, Contribución 235: 1-22.

Clément A \& G Lembeye. 1993. Phytoplankton monitoring program in the fish farming region of South Chile. In: Smayda TJ \& Y Shimizu (eds). Toxic phytoplankton blooms in the sea, pp. 223-228. Elsevier, Amsterdam.

Charpy C \& L Charpy. 1977. Biomasse phytoplanctonique, production primaire et facteurs limitant la fertilité des eaux du Golfe 'San José' (Péninsule Valdes, Argentine). Thèse, Centre Universitaire de Marseille-Luminy, Université d' aix-Marseille II, Marsella, 186 pp.

Evensen DL \& GR Hasle. 1975. The morphology of some Chaetoceros (Bacillariophyceae) species as seen in the electron microscopes. Nova Hedwigia, Beiheft 53: 153-184.

Ferrario ME \& NM Galván. 1989. Catálogo de las diatomeas marinas citadas entre los $36^{\circ}$ y los $60^{\circ} \mathrm{S}$ con especial referencia al Mar Argentino. Instituto Antártico Argentino, Publicación 20: 1-327.

Ferrario ME, EA Sar \& RG Codina. 1986. Diatomeas marinas de la Provincia de Chubut (República Argentina). Centrales I. Darwiniana 27: 89-106.

Ferrario ME, EA Sar \& SE Sala. 1995. Metodología básica para el estudio del fitoplancton con especial referencia a las diatomeas. In: Alveal K, ME Ferrario, EC Oliveira \& EA Sar (eds). Manual de Métodos Ficológicos, pp. 1-23. Universidad de Concepción, Concepción.

Frenguelli J. 1928. Diatomeas del Océano Atlántico frente a Mar del Plata. Anales del Museo Nacional de Historia Natural 'Bernardino Rivadavia' 34, Protistología 1: 497609.
Frenguelli J. 1935. Variaciones de Dictyocha fibula en el Golfo San Matías. Anales del Museo Argentino de Ciencias Naturales 'Bernandino Rivadavia' 38, Protistología 4: 265281.

Frenguelli J. 1939. Diatomeas de Rada Tilly en el Golfo San Jorge (Chubut). Revista del Museo de La Plata (nueva serie) 2, Botánica 9: 179-201.

Frenguelli J \& H Orlando. 1959. Operación Merluza. Diatomeas y silicoflagelados del plancton del 'VI Crucero', República Argentina. Servicio de Hidrografía Naval, Buenos Aires. Publicaciones Técnicas Oceanográficas. H 619: 1-62.

Fryxell GA \& GR Hasle. 2004. Taxonomy of harmful diatoms. In: Hallegraeff GM, DM Anderson \& AD Cembella (eds). Manual on Harmful Marine Microalgae, pp. 465-509. Intergovernmental Oceanographic Commission of UNESCO, Paris.

Fryxell GA \& LK Medlin. 1981. Chain forming diatoms: evidence of parallel evolution in Chaetoceros. Cryptogamie, Algologie 2: 3-29.

Gayoso AM. 1999. Seasonal succession patterns of phytoplankton in the Bahía Blanca Estuary (Argentina). Botanica Marina 42: 367-375.

Gayoso AM. 2001. Observations on Alexandrium tamarense (Lebour) Balech and other dinoflagellate populations in Golfo Nuevo, Patagonia (Argentina). Journal of Plankton Research 23: 463-468.

Giuffrè G \& S Ragusa. 1988. The morphology of Chaetoceros rostratus Lauder (Bacillariophyceae) using light and electron microscopy. Botanica Marina 31: 503-510.

Gogorev RM, TY Orlova, OG Shevchenko \& IV Stonik. 2006. The Diatoms of Russia and adjacent countries. Fossil and recent. 2(4) Chaetocerotales (Chaetocerotaceae, Acanthoceratiaceae, Attheyaceae), pp. 1-180. St. Petersburg University Press, Saint Petersburg.

Gran HH. 1908. XIX Diatomaceae. In: Brandt K \& C Apstein (eds). Nordisches Plankton. Botanischer Teil 8 (19): 1-146. Lipsius \& Tischer, Kiel und Leipzig.

Hargraves PE. 1972. Studies on marine plankton diatoms. I. Chaetoceros diadema (Ehr.) Gran: life cycle, structural morphology, and regional distribution. Phycologia 11: 247257.

Hargraves PE. 1979. Studies on the marine plankton diatoms IV. Morphology of Chaetoceros resting spores. Nova Hedwigia, Beiheft 64: 99-120.

Hargraves PE \& L Maranda. 2002. Potentially toxic or harmful microalgae from the northeast coast. Northeastern Naturalist 9: 81-120.

Hasle GR \& GA Fryxell. 1970. Diatoms: cleaning and mounting for light and electron microscopy. Transactions of the American Microscopical Society 89: 469-474.

Hasle GR \& EE Syvertsen. 1996. Marine Diatoms. In: Tomas CR (ed). Identifying Marine Phytoplankton, pp. 5-385. Academic Press, San Diego. 
Hendey NI. 1937. The plankton diatoms of the Southern Seas. Discovery Reports 16: 151-364.

Hernández-Becerril DU. 1991. Note on the morphology of Chaetoceros didymus and C. protuberans, with some considerations on their taxonomy. Diatom Research 6: 289297.

Hernández-Becerril DU. 1993a. Note on the morphology of two planktonic diatoms: Chaetoceros bacteriastroides and C. seychellarus, with comments on their taxonomy and distribution. Botanical Journal of the Linnean Society 111: 117-128.

Hernández-Becerril DU. 1993b. Study of the morphology and distribution of two planktonic diatoms: Chaetoceros paradoxus and Ch. filiferus (Bacillariophyceae). Cryptogamic Botany 3: 169-175.

Hernández-Becerril DU. 1996. A morphological study of Chaetoceros species (Bacillariophyta) from the plankton of the Pacific Ocean of Mexico. Bulletin of the Natural History Museum of London (Botany) 26: 1-73.

Hernández-Becerril DU \& C Flores Granados. 1998. Species of the diatom genus Chaetoceros (Bacillariophyceae) in the plankton from the Southern Gulf of Mexico. Botanica Marina 41: 505-519.

Horner RA, DL Garrison \& FG Plumley. 1997. Harmful algal blooms and red tide problems on the U.S. west coast. Limnology and Oceanography 42: 1076-1088.

Jensen K \& Ø Moestrup. 1998. The genus Chaetoceros (Bacillariophyceae) in inner Danish coastal waters. Opera Botanica 133: 1-68.

Karsten G. 1907. Das Indische Phytoplankton nach dem Material der Deutschen Tiefsee-Expedition 1898-1899. Deutschen Tiefsee-Expedition 1898-1899 2 (2): 221-598.

Koch P \& P Rivera. 1984. Contribución al conocimiento de las diatomeas chilenas. III. El género Chaetoceros Ehr. (subgénero Phaeoceros Gran). Gayana, Botánica 41: 6184.

Koch P \& P Rivera. 1988. Taxonomía y morfología de cinco especies de Chaetoceros Ehrenberg (Subgénero Hyalochaete Gran) de las aguas costeras de Chile. Ciencia y Tecnología del Mar 12: 109-135.

Lange C. 1985. Spatial and seasonal variations of the diatom assemblages off the Argentinian coast (South Western Atlantic). Oceanologica Acta 8: 361-370.

Marino D, G Giuffré, M Montresor \& A Zingone. 1991. An electron microscope investigation on Chaetoceros minimus (Levander) comb. nov. and new observations on Chaetoceros throndsenii (Marino, Montresor \& Zingone) comb. nov. Diatom Research 6: 317-326.

Marques da Cunha A \& O Da Fonseca. 1917. O microplancton do Atlantico nas imediações de Mar del Plata. Memorias do Instituto Oswaldo Cruz 9: 3-5.

Müller Melchers FC. 1953. New and little known diatoms from Uruguay and the South Atlantic Coast.
Comunicaciones Botánicas del Museo de Historia Natural de Montevideo 30: 1-25.

Müller Melchers FC. 1955. Las diatomeas del plancton marino de las costas del Brasil. Boletim do Instituto Oceanográfico, Saõ Pablo 6: 90-138.

Negri RM, NG Montoya, JI Carreto, R Akselman \& D Inza. 2004. Pseudo-nitzschia australis, Mytilus edulis, Engraulis anchoita, and domoic acid in the Argentine Sea. In: Steidinger KA, JH Landsberg, CR Tomas \& GA Vargo (eds). Harmful Algae 2002, pp. 139-141. Florida Fish and Wildlife Conservation Commission, Florida Institute of Oceanography, and Intergovernmental Oceanographic Commission of UNESCO, St. Petersburg.

Nikolaev VA. 1993. The 'pore' apparatus of centric diatoms: A description of terms. Nova Hedwigia, Beiheft 106: 3342.

Ostenfeld CH. 1903. Phytoplankton from the sea around the Færöes. In: Warning E (ed). Botany of the Færöes II, pp. 559-611. Nordish Forlag, Copenhague.

Procopiak LK, LF Fernandes \& H Moreira Filho. 2006. Marine and estuarine diatoms (Bacillariophyta) from Parana, southern Brazil: check-list with emphasis on harmful species. Biota Neotropica Sep/Dec 2006 6(3). http://www.biotaneotropica.org.br/v6n3/pt/ abstract?inventory+bn02306032006. [Fecha de visita 5-1107]

Proschkina-Lavrenko AI \& IV Makarova. 1968. Vodorosli planktona Kaspiskogo Moria, pp. 1-290. Akademia Nauk SSSR, Leningrado.

Prygiel J \& M Coste. 2000. Guide Méthodologique pour la mise en ouvre de l'Indice Biologique Diatomées, pp. 1134. Agences de l'Eau, Ministére de l'Aménagement du Territoire et de l'Environnement, Direction de l'Eau \& CEMAGREF, Paris.

Rines JEB. 1999. Morphology and taxonomy of Chaetoceros contortus Schütt 1895, with preliminary observations on Chaetoceros compressus Lauder 1864 (Subgenus Hyalochaete, Section Compressa). Botanica Marina 42: 539-551.

Rines JEB \& PE Hargraves. 1988. The Chaetoceros Ehrenberg (Bacillariophyceae) flora of Narragansett Bay, Rhode Island, U.S.A. Bibliotheca Phycologica 79: 1-196.

Rines JEB \& PE Hargraves. 1990. Morphology and taxonomy of Chaetoceros compressus Lauder var. hirtisetus var. nova, with preliminary consideration of closely related taxa. Diatom Research 5: 113-127.

Rines JEB \& EC Theriot. 2003. Systematics of Chaetocerotaceae (Bacillariophyceae). I. A phylogenetic analysis of the family. Phycological Research 51: 83-98.

Romero O \& C Hensen. 2002. Oceanographic control of biogenic opal and diatoms in surface sediments of the Southern Atlantic. Marine Geology 186: 263-280.

Ross R, EJ Cox, NI Karayeva, DG Mann, TBB Paddock, R Simonsen \& PA Sims. 1979. An amended terminology for 
the siliceous components of the diatom cell. Nova Hedwigia, Beiheft 64: 513-533.

Round FE, RM Crawford \& DG Mann. 1990. The Diatoms. Biology and Morphology of the Genera, pp. 747. Cambridge University Press, Cambridge.

Sar EA. 1996. Flora diatomológica de Bahía San Antonio (Prov. de Río Negro, Argentina) O. Centrales I. Revista del Museo de La Plata (nueva serie) 14, Botánica 106: 365-400.

Sar EA, DU Hernández-Becerril \& I Sunesen. 2002. A morphological study of Chaetoceros tenuissimus Meunier, a little-known planktonic diatom, with a discussion of the section Simplicia, subgenus Hyalochaete. Diatom Research 17: 327-335.

Smayda TJ. 2006. Diatom Blooms and fish mortality. In: Scottish Executive Environment Group, Harmful Algal Bloom Communities in Scottish Coastal Waters: Relationship to Fish Farming and Regional Comparisons A Review. http//www.scotland.gov.uk/Publications. [Fecha de visita 21/2/06]

Shevchenko OG, TY Orlova \& DU Hernández-Becerril. 2006. The genus Chaetoceros (Bacillariophyta) from Peter the Great Bay, Sea of Japan. Botanica Marina 49: 236-258.
Stockwell DA \& PE Hargraves. 1986. Morphological variability within resting spores of the marine diatom genus Chaetoceros Ehrenberg. In: Ricard M (ed). Proceedings of the Eighth International Diatom Symposium, pp. 81-96. Koeltz Scientific Books, Koenigstein.

Torgan LC, V Becker \& HM Prates. 1999. Checklist das diatomáceas (Bacillariophyceae) de ambientes de águas continentais e costeiros do Estado do Rio Grande do Sul. Iheringia, Série Botânica 52: 89-144.

Vargas-Montero M \& E Freer. 2004a. Paralytic shellfich poisoning outbreaks in Costa Rica. In: Steidinger KA, JH Landsberg, CR Tomas \& GA Vargo (eds). Harmful Algae 2002, pp. 482-484. Florida Fish and Wildlife Conservation Commission, Florida Institute of Oceanography, and Intergovernmental Oceanographic Commission of UNESCO, Paris.

Vargas-Montero M \& E Freer. 2004b. Proliferaciones algales de la diatomea toxigénica Pseudo-nitzschia (Bacillariophyceae) en el Golfo de Nicoya, Costa Rica. Revista de Biología Tropical 52(Suppl. 1): 127-132.

Vouilloud AA. 2003. Catálogo de diatomeas continentales y marinas de Argentina. Asociación Argentina de Ficología, La Plata. Versión 1.0. ISBN 987-21041-0-7. [Formato digital]

Recibido el 14 de enero de 2008 y aceptado el 14 de mayo de 2008 